\title{
An Analysis of the Level of Qualitative Efficiency for the Equity Research Reports in the Italian Financial Market
}

\author{
Paola Fandella ${ }^{1}$ \\ ${ }^{1}$ Università Cattolica del Sacro Cuore, Italy \\ Correspondence: Paola Fandella, Università Cattolica del Sacro Cuore, Italy.
}

Received: January 15, 2018

Accepted: February 6, 2018

Online Published: February 8, 2018

doi:10.5430/ijba.v9n2p21

URL: https://doi.org/10.5430/ijba.v9n2p21

\begin{abstract}
Corporate reports issued by various financial intermediaries play a major role in investment decisions. For this reason, it is particularly interesting to understand the accuracy of the forecasts, by carrying out an empirical analysis of the "equity research" system in Italy, identifying structural features, degree of reliability and incidence in the market. The choice of the analysis of the efficiency level information on the Italian market proposes to assess the interest of equity research of a niche market (339 listed companies in 2017) but with characteristics of potential growth such as having been acquired by LSEGroup in 2007, the 6th stock-exchange group at international level for the number of listed companies and the 4th for capitalization.

The analysis was carried out on the reports issued on companies belonging to the Ftse Mib stock index during a period of 5 years.

It aims to analyse the composition of the equity research system in Italy as well as the analysts' ability to properly evaluate the stocks' fair price, so as to test their degree of reliability and detect possible anomalies in recommendations to the investors.
\end{abstract}

Keywords: financial intermediaries, equity research, forecasts efficiency, Italian market

JEL Codes: G11, G14, G17, G24

\section{Introduction}

A large number of corporate reports on the economic forecasts of listed companies are issued every year by main merchant banks, brokerage firms and equity research experts in all countries having financial markets. (Johnson 2006) In practice, reports play a major role in providing a considerable information flow to the market, reducing, at the same time, the costs of data collection usually incurred by investors; thus, they represent some sort of "operative trend-setters" aimed at spurring a proactive attitude in terms of buy and sell orders. Reports may be defined as a "filtering" information system, in the form of an evaluative approach to the system of information that the so-called "well-informed investors" outline for the "common" investor.

For this reason, the forecasts contained in these "institutional" researches exert a remarkable incidence, both on the creation of market expectations on corporate financial performances, and on investment decisions, affecting also the quotation of the stocks examined, according to the efficient markets' theory distinguishing from professional investor, investor with derivatives information and non-informed investor (Fama, 1970).

In this analysis, another interesting element is the fact that, despite the large number of studies on the impact of reports on quotations and traded volumes published in the last years, only limited academic attention has surprisingly been paid, specifically in recent years, to the accuracy of forecasts in corporate reports, and in particular to the analysts' ability to release reliable target prices. Only in recent times has increasing academic interest been devoted to these issues, as if the process of evaluation of information at the institutional or, more generally, professional level had nothing to do with the reliability of the final result (Asquith, 2005; Belcredi, 2003; Brav-Leahvy, 2003; Cervellati-Della Bina-Pattitoni, 2008).

This is an unusual situation, and it may be deemed specular opposite if we consider target prices as elements that can be perceived directly, and that provide an immediate measurement of the variation in stock price expected by analysts; as such, they can be seen as factors that can strongly influence investment decisions 
(Bonini-Zanetti-Bianchini-Salvi, 2010).

It is well known that intermediation in market information dynamics is an activity that derives, physiologically we may say, from a natural state termed "information asymmetry", that is to say from the chronic gap of knowledge existing between issuing companies and investors, and from the-rational-impossibility for the latter to fill in this gap personally (even in a compulsory disclosure system binding the former) (Fusconi, 2010).

It goes without saying that financial analysts play a leading role in the intermediation of these information dynamics between intermediaries (well-informed investors), since they find themselves involved in the collection and study of corporate economic and financial data compared to relative sectors of reference markets and stock price trends. This results in the formulation of articulated suggestions about business performance and risk prospects, in the form of operationally synthetic, and easily graspable, evaluations (such as "buy", "hold", "sell", often followed by target prices) with respect to the financial tools under consideration. It is evident that in the perspective of market efficiency, production of this information must be judged in a positive way (even if it mostly derives from data and news collected by the issuer, or in any case available), insofar as it contributes to more accurate stock pricing and, consequently, to a reduction of adverse selection situations for companies, as well as an increase in consumer confidence (Bradshaw-Brown, 2006).

Furthermore, market reactions taking place after the issuing of reports-especially those containing a revision of recommendations or target prices-implicitly confirm the reliability and confidence that investors put in analysts' forecasts. This is because they integrate the information framework upon which investment evaluations are based, and/or they even replace the evaluation process by directly "using" the suggestion shown in the report. As a matter of fact, the substitution/duplication effect can typically be found in the behaviour of those subjects who can decode the market, such as private investors collecting and using "institutional" information to orient their investments. The results of the analyses below will show whether the market tendency towards duplication (on the basis of the results conveyed by the reports) is able to achieve objectives aimed at the optimization of investments-even if it is indirect, since it provokes a duplication and therefore a physiological delay in performing and thus if, also from this perspective, the researchers are accurate and suitable to represent that "filter" of informative evaluation attributed $a$ priori to professional operators (De Vincentis, 2010).

The following empirical analysis, instead, can be suitable to verify a posteriori two different incidence rates in the market. The first one evaluates the possibility that research attains its market objectives, that is to say whether it has any effects on stock price. The second one, undoubtedly less immediate, aims at verifying if this activity can also produce derived information, that is, a type of information that can directly spur a substitution effect between research and underlying asset, since investors tend to follow instructions passively-also in a time-saving logic and independently from other factors, a fact which testifies to the decoding nature of the market which is increasingly vulnerable to unforeseen and un-codified events (Wormack, 1996).

\section{Sample and Descriptive Statistics. The Formulation of the Sample of the General Data and the Information Contained in the "Reports"}

The analysis considers corporate studies issued by financial intermediaries from October $1^{\text {st }}, 2012$ to December $31^{\text {st }}$, 2016 on the 40 securities belonging to the Ftse Mib Italian stock index as at December $1^{\text {st }}, 2016$. The choice of the analysis of the efficiency level information on the Italian market proposes to assess the interest of equity research of a niche market (339 listed companies in 2017) but with characteristics of potential growth such as having been acquired by LSEGroup in 2007, the 6th stock-exchange group at international level for the number of listed companies and the 4th for capitalization.

The data collection and classification of corporate studies was carried out considering data from reports on each security examined issued by the various financial intermediaries and published on Bloomberg.

The sample was there formed by 11322 corporate reports, issued by 93 research firms (Note 1), over the 5 years considered.

A first general analysis of the system features can be based on the summary statements contained in the reports, that is the types of information provided by the market analysts.

This analysis is contained in Table 1 and underlines that 11322 corporate reports, representing $100 \%$ of the sample, include an explicit recommendation (Note 2), while 10290 (90.9\%) reports (Note 3) include an explicit recommendation as well as a target price. 
Table 1. Reports total breakdown per recommendations/target price

\begin{tabular}{llll}
\hline & Reports & Recommendations & Target price \\
\hline$N^{\circ}$ & 11322 & 11190 & 10290 \\
$\%$ & $100 \%$ & $98.8 \%$ & $90.9 \%$ \\
\hline
\end{tabular}

The high number of statements containing recommendations and target prices suggests that, as a result of their analysis, the analysts adopt a "fixed" position, by formulating a suggestion on the equity future performance and expressing a target price referred to the same performance.

The analysts' tendency to formulate just the recommendations or express also explicit target prices in the corporate reports they produce can also be analysed by disaggregating data by years and months.

The tables below show the general data breakdown by year [Table 2 (Panel A), Table 2 (Panel B)].

Table 2 (Panel A). Reports total breakdown per recommendation/target price by year (absolute value)

\begin{tabular}{cccc}
\hline & Reports & Recommendations & Target price \\
\hline 2016 & 2593 & 2576 & 2379 \\
2015 & 2451 & 2428 & 2241 \\
2014 & 2273 & 2245 & 2036 \\
2013 & 2006 & 1977 & 1813 \\
2012 & 1999 & 1964 & 1821 \\
Total & 11322 & 11190 & 10290 \\
\hline
\end{tabular}

Table 2 (Panel B). Reports total breakdown per recommendation/target price by year (\% value)

\begin{tabular}{llll}
\hline & Reports & Recommendations & Target price \\
\hline 2016 & $100 \%$ & $99.3 \%$ & $91.7 \%$ \\
2015 & $100 \%$ & $99.1 \%$ & $91.4 \%$ \\
2014 & $100 \%$ & $98.8 \%$ & $89.6 \%$ \\
2013 & $100 \%$ & $98.5 \%$ & $90.4 \%$ \\
2012 & $100 \%$ & $98.2 \%$ & $91.1 \%$ \\
\hline Total & $100 \%$ & $98.8 \%$ & $90.9 \%$ \\
\hline
\end{tabular}

The overall interpretation of the figures and the percentages shown in the table confirms the presence of an average prudential component but even if the number of reports containing "only" a recommendation exceeds the number of reports with an explicit target price for all the years the gap is not relevant.

This can be also observed by considering the data breakdown of the type of information contained in the reports by month (Table 3 in the appendix).

This tendency may also indicate that analysts decide to adopt a certain type of behaviour, and provide accurate information inputs.

A typical feature of the recommendation is "to implicitly contain a temporal projection within which the advice is expressed, so it has longer incidence times even in terms of reliability judgment. The target price, on the other hand, exploits the rate of absorption of market prices and is more susceptible to the perception of variability, even on behalf of the investor using the suggestions of the report"(Fandella, 2012).

From Tables 4 (Panel A), (Panel B) and (Panel $C$ ) in the appendix, showing the details on the number of reports by equity and on the type of information delivered, as well as the aggregated data by industry class; it is possible to see for each company the type of information input mainly provided by the financial intermediaries forming the equity research system.

From the analysis of Table 4 (Panel B) and (Panel C), it emerges that the highest degree of explicit information can be found in reports on Financials (3631), Consumer Discretionary (1978), Energy (1781), Industrials (1172) and Utilities (1055) with high level of rating (in order 98.6\%, 99.5\%, 98.7\% and 99.5\%), while for Telecommunication Services that percentage falls to $93.3 \%$ with only 579 reports. 
To better understand the performance analysis in the reports, it could be useful to give a look at the performance of the Ftse Mib stock index during the period examined by this study.

In the first half of 2012, the index recorded a number of downturns, particularly in May and July. In July, the downturn brought the index to lose $20 \%$ to 12362.51 points.

Starting from September 2012, the Ftse Mib saw a general bullish trend. Its value passed from 12362.51 points in July 2012 (down 20\%) to 22502.97 points in June 2014 (up 43\%).

This does not mean, however, that there have not been declines in the index value over this period of time, including those recorded in March 2013, July 2013 and the most recent one in August 2014, which saw the value of the index fall to 19130.65 points $(21.34 \%)$.

In the second half of 2014 the market lost $20 \%$ to 18078.97.

Starting from January 2015, the index saw a huge increase. Its value reached 24030.54 in April and 24031.19 in July 2015 (up more than 30\%). After that, the Ftse Mib experienced a significant downturn (down 37.15\% to 15103.58 in June 2016).

Only at the end of 2016 the value of the index rebounds to more than 19300 points with a $28 \%$ gain.

This situation would lead to create the expectation that the distribution of the analysts' recommendations is probably biased by the different market trends.

Referring to the report performance analysis, no matter what the index's performance was, this should not have affected the target price reliability level.

In effect, if brokers' ability to make predictions about the future performance of equity securities is recognised as better than the average, given that they use more in-depth and accurate information, it is reasonable to expect a fairly high forecasting accuracy, regardless of market performance.

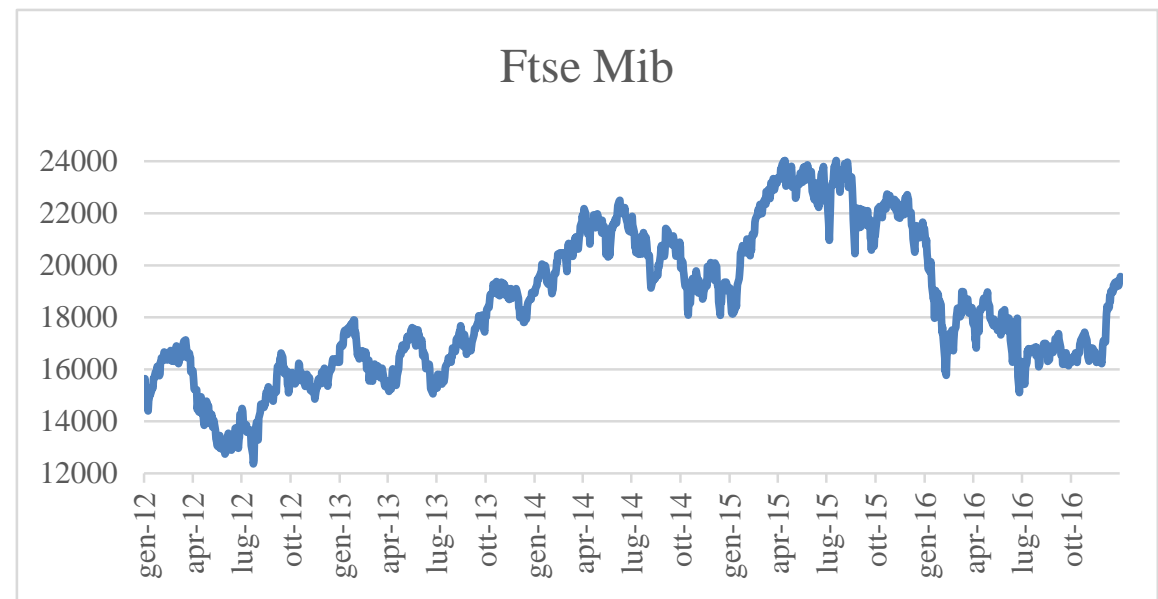

Figure 1. Ftse mib index performance-January 2012-December 2016

Source: Bloomberg

\section{The Analysis}

\subsection{The Recommendations Distribution}

The rating systems used by the different brokers are not homogeneous. In order to identify categories to reclassify ratings, a 3-value scale was adopted, as shown in Table 5. 
Table 5. Reclassification of recommendations, listed by decreasing degree of positivity

\begin{tabular}{ccc}
\hline Positive recommendations & $\begin{array}{c}\text { Neutral } \\
\text { Recommendations }\end{array}$ & Negative recommendations \\
\hline Buy & Hold & Underweight \\
Selected list & Neutral & Underperform \\
Outperform & & Reduce \\
Overweight & & Sell \\
\hline
\end{tabular}

On a sample of 11190 corporate reports containing an explicit recommendation, $40.7 \%$ consisted of positive recommendations, $42.2 \%$ of neutral recommendations and $17.1 .6 \%$ of negative recommendations (Table 6 Panel A).

Table 6 (Panel A). Recommendations breakdown by type of operational "suggestions". (Absolute and percentage values on reports with recommendations)

\begin{tabular}{lllll}
\hline & Recommendations & Positive & Neutral & Negative \\
\hline$N^{\circ}$ & 11190 & 4555 & 4726 & 1909 \\
$\%$ & $100 \%$ & $40.7 \%$ & $42.2 \%$ & $17.1 \%$ \\
\hline
\end{tabular}

Recommendations distribution shows that the analysts are clearly inclined to give positive operational "suggestions". Only $17.1 \%$ of the issued recommendations are negative.

For a more complete analysis, the table under consideration should be analysed along with Table 6 (Panel B), which is included in the appendix, which specifically recalls the data on the recommendations collected for each basket title, detailing the positive, neutral and negative recommendations, and along with Table 6 (Panel C), also included in the appendix, which provides details of the distribution of recommendations for each sector class represented within the Ftse Mib index.

The first results confirm the above-mentioned analysis of Table 6 that is the widespread optimism in the reports, also confirmed by the distribution of the recommendations by company and by sector class. In particular, it is not possible to ignore the percentages of positive ratings that characterise the Industrial sector class, for which positive recommendations account for $53.4 \%$ of the total of issued reports as opposed to a negligible $11.7 \%$ of negative recommendations. High percentages can also be seen in the sector of Telecommunication Services (48.5\%) with only $10.0 \%$ of negative recommendations.

Interpreting these data, two considerations that may explain analysts' widespread optimism should be taken into account: first, starting from January 2012, after the significant downturns recorded from 2009 to 2011, the Ftse Mib began to experience a general bullish trend till mid-2014, although index downturn periods continue to be present. After that period the index entered in a more volatile environment with robust upward trends followed by strong losses; second, a recommendation typically encapsulates a predictive meaning in itself. According to this perspective, it is possible to interpret the propensity of analysts to make positive operational recommendation as a suggestion to understand the circumstances under which certain equities are over weighted, since the circumstances may be merely systemic and not closely related to the performance potential of the equity itself.

\subsection{The Comparison between the Value of the Average Recommendation and Equity Index Performance}

This comparison aims to verify whether there is a relation between the past performance of the Ftse Mib equity index and the average of the issued recommendations.

For this purpose, a "monthly average recommendation" was calculated for each of the 60 months of the period under consideration, and its trend was compared with that of the equity index.

Should such a relation be confirmed, there would be an increase in positive recommendations and optimistic target prices in the bullish market phases, and a greater presence of negative recommendations when the market is going through bearish phases.

However, this behaviour should not be adopted by a financial analyst who should seek to find the fair price of a stock and therefore advise on an effective strategy rather than a strategy that adapts to the market trends.

The recommendations issued in the same month were taken into account to calculate the "monthly average recommendation", so positive recommendations were "weighed" with value $(+1)$, neutral recommendations with value (0) and negative recommendations with value (-1). 
As for the index performance, the study took into account the nominal values on the Italian index on the first quotation day of the month.

The comparison was then done with a one-month shift, that is the value of the index, and thus its subsequent variations, and was compared to the average recommendation calculated in the following month, in order to allow the observation of the possible relations between the past performance of the index and the average of the recommendations issued. Table 7, in the appendix, shows the relative values.

The Fihure below-Figure 2 shows the two performances.

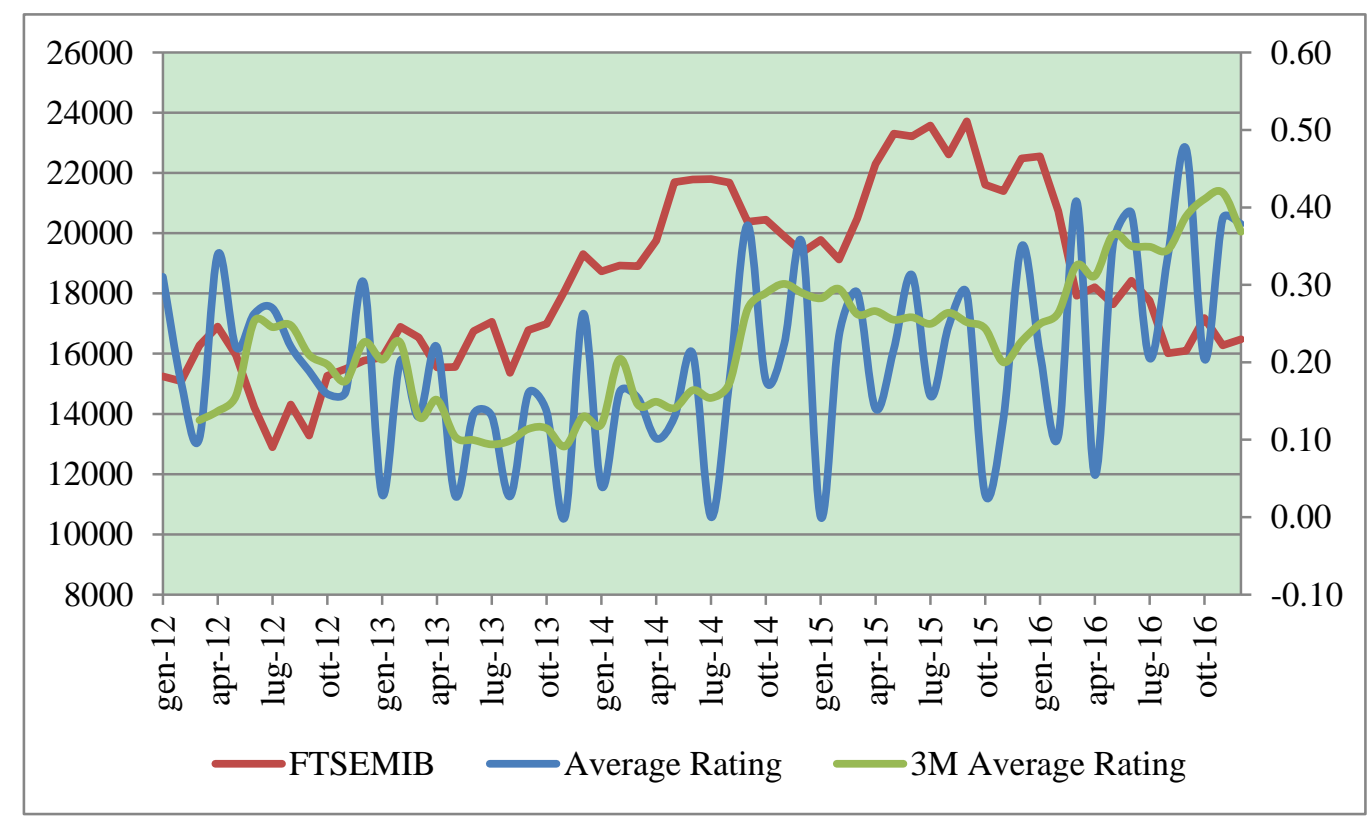

Figure 2. Comparison Ftse Mib index-Average rating performance

From the proposed Figure, it is possible to find a similarity in the trend of the two curves especially between the index and 3 months moving average of the mean rating. Although they are characterised by different volatility, both experience a rising trend during the bullish market phases and are decreasing during the bearish market phases.

This phenomenon is confirmed also by the analysis of the comparison made between the monthly average recommendation and the equity index performance, Table 7 in the appendix.

In fact, it can be noted that, considering a certain temporal lag, the average recommendation tends to mimic the index pattern.

The analyst's recommendations and target prices are therefore influenced by the past performance of the index, while it would be desirable, as stated above, that a financial analyst focused on identifying the fair price of a stock in order to suggest an effective strategy rather than a strategy that adapts to market trends.

\section{3 "Target price" Reliability}

The analysis of target price reliability undoubtedly plays a major role in verifying the quality of information inputs provided by financial intermediaries and making up the equity research system.

This analysis is also important as it allows the measurement of the degree of reliability of the target price forecasts, formulated by analysts, in an instant manner, precisely because of the comparison between estimated prices and market performance.

If it were not possible to evaluate the actual accuracy of the estimated target prices, the analysts themselves would be less inclined to produce accurate analyses since reputational risk would be very limited if not absent.

\subsubsection{Some Notes on the Methodology}

The first methodological choice to be clarified concerns the time horizon within which to evaluate the achievement 
of the target price, since most reports do not contain specifications of the time horizon within which the forecasts should occur.

A choice commonly made is to adopt a 12 month time horizon, a shared choice adopted in the research on which the analysis contained in this paper is based and carried on.

The present analysis has therefore estimated a target price as correct when, at any time within 12 months from the date of the release of the report, the stock price equalled the price indicated by the analyst. For this purpose, during the analysis, for each figure, only the "end of days" prices and the "intraday" deviations were not taken into account in the given period.

In the case of two or more recommendations issued by the same intermediary at a shorter distance than that of the chosen time horizon, it was decided to verify the goodness of the report up to its "natural expiration date" so that it would not end its validity at the time a new one was released.

The analysis of reports containing an indication of the target price reveals that, as shown in Table 8, within 12 months after the issue, the target price was hit in $56.0 \%$ of the cases.

The same type of analysis aiming to measure the accuracy of the target price was then conducted by admitting a margin of 5\% in order to assess whether there was a significant increase in the reliability by introducing a certain degree of tolerance in the evaluation.

With this method, the correct target prices were $65.8 \%$ of the sample.

Table 8. Accuracy of the target prices

\begin{tabular}{llll}
\hline & Reached target price & $+/-5 \%$ reached target price & Total target price \\
\hline$N^{\circ}$ & 5766 & 6775 & 10290 \\
$\%$ on the Total & $56.0 \%$ & $65.8 \%$ & $100 \%$ \\
\hline
\end{tabular}

The figures show that the ability to issue reliable target prices is just sufficient, and suggest that the result may be rather attributed to the randomness of market performance.

The result improves, only recognising $5 \%$ discretion.

This means that even though intermediaries are recognised to have an ability in forecasting the future performance of equity securities superior to the average, taking into account that they have more in-depth and accurate information, they do not excel in the obtained results, highlighting limits on the methods of analysis used in the context of equity research.

Table 9 in the appendix shows the reliability level specifically recorded for all the 40 equities of the Ftse Mib index: only for Brembo, Terna and Buzzi Unicem the levels of reached target price are more than $80 \%(89.2 \%, 84.0 \%$ and $82.2 \%)$.

On the other hand, Table 10, reported here below, enables to underline the comparison on the accuracy of the target price between the five equities that received the highest number of reports and the five least analysed stocks in the equity research.

This is due to the fact that, according to some theses expounded in the literature (Bonini-Zanetti-Bianchini-Salvi, 2010), there should be some kind of competition between the studies issued by the various analysts on the higher capitalisation securities, since this is the kind of equities which are more frequently present in the client portfolios, and therefore the object of more reports.

Competition between analysts should, in theory, lead to an increase in the quality of the reports and, consequently, to greater reliability of the target price. 
Table 10. Comparison on the accuracy of the target price between the 5 equities with the highest number of target price forecasts and the five equities with the lowest number of target price forecasts

\begin{tabular}{lccccc}
\hline \multicolumn{1}{c}{ Equity } & Target Price & \multicolumn{2}{c}{ Reached TP } & \multicolumn{2}{c}{+ +/ 5\% Reached TP } \\
& $N^{\circ}$ & $N^{\circ}$ & $\%$ & $N^{\circ}$ & $\%$ \\
\hline 1 UNICREDIT SPA & 567 & 0 & $0.0 \%$ & 0 & $0.0 \%$ \\
2 ENI SPA & 553 & 276 & $49.9 \%$ & 386 & $69.8 \%$ \\
3 INTESA SA NPAOLO & 535 & 316 & $59.1 \%$ & 372 & $69.5 \%$ \\
4 ASSICURAZIONI GENERALI & 496 & 285 & $57.5 \%$ & 369 & $74.4 \%$ \\
5 TELECOM ITALIA SAP & 485 & 254 & $52.4 \%$ & 304 & $62.7 \%$ \\
36 FINECOBA NK SPA & 62 & 34 & $54.8 \%$ & 46 & $74.2 \%$ \\
37 FERRA RI NV & 57 & 34 & $59.6 \%$ & 39 & $68.4 \%$ \\
38 POSTE ITALIANE SPA & 47 & 3 & $6.4 \%$ & 11 & $23.4 \%$ \\
39 BANCA MEDIOLANUM SPA & 22 & 11 & $50.0 \%$ & 18 & $81.8 \%$ \\
40 ITALGAS SAP & 16 & 2 & $12.5 \%$ & 4 & $25.0 \%$ \\
\hline
\end{tabular}

However, in the analysis, there is no evidence that the equities object of more reports enjoy more accurate forecasts. Indeed, the results obtained on the five equities subject to a more intense research activity show a very low level of reliability in target prices.

In particular, above all for Unicredit, but also for Eni and Telecom, accuracy percentages are lower than the average. The remaining equity, Intesa SanPaolo and Assicurazioni Generali, though characterised by a higher percentage of accuracy than the average, does not achieve a significant result in terms of precision, approaching it only if we consider the $5 \%$ discretionary range.

Very similar results can be appreciated also from the interpretation of data referred to the 5 equities with a much smaller number of reports.

\subsection{The Ratio between "Target Price" and Current Price}

For all reports with an explicit price indication, the present study has calculated the ratio between the target price and the current price of the security, that is the price recorded at the time the report was issued (TP/P ratio) (Note 4)

This ratio is an indicator of the percentage deviation between the target price and the current price, so it is possible to identify the expected average variation of the securities under study.

Under normal conditions, with a sufficiently large sample and with uniformly distributed recommendations, among positives, neutrals and negatives, the expectation would be that this average value tended to zero.

However, in the sample being analysed, a larger majority of positive recommendations was repeatedly found, which is why it is reasonable to assume that this relation assumes a positive value.

The average TP/P ratio obtained is equal to $10.9 \%$ as shown in Table 11 reported here below.

This percentage shows that, on average, registered target prices, regardless of the type of recommendation they relate to, whether positive, neutral or negative, included an upside margin of about $10 \%$ of the stock within the considered time horizon of 12 months.

In order to find out more clearly the determinants of this result, the TP/P ratio was calculated for each of the three types of recommendations considered: positive, neural and negative as shown in Table 11.

Table 11. TP/P ratio for the three recommendation categories

\begin{tabular}{lccc}
\hline & $N^{\circ}$ & $\%$ & Average TP/P ratio \\
\hline Positive & 4555 & $40.7 \%$ & $23.01 \%$ \\
Neutral & 4726 & $42.2 \%$ & $7.2 \%$ \\
Negative & 1909 & $17.1 \%$ & $-11.1 \%$ \\
Total & 11190 & $100 \%$ & $10.9 \%$ \\
\hline
\end{tabular}


With reference to the total number of corporate reports containing an explicit recommendation, the distribution and the percentages of the specific weight for each type of recommendation are reported: positive $40.7 \%$; Neutral $42.2 \%$; Negative $17.1 \%$.

Table 12, contained in the appendix, presents the average TP/P ratio values calculated for the 40 securities belonging to the Ftse Mib stock index.

Once again, the figures show a positive asymmetry. In a normal situation, similar figures would be expected in absolute terms for positive and negative recommendations, and a zero-point value for neutral recommendations.

The situation presented by the data is different, as target prices are characterised by a high, perhaps excessive, optimism with expected average growth rates, within twelve months, of $10.9 \%$ medium and of $23 \%$ with rating Buy.

This percentage does not reflect a common growth scenario. Very optimistic forecasts also characterise neutral recommendations.

The result on the 11190 corporate reports covered by this analysis is therefore determined not only by the prevalence of positive recommendations, but also by the presence of ambitious target prices.

They are countered by a much smaller number of negative recommendations, containing target prices which foresee a much lower contraction than the optimistic average growth rates expected. This asymmetry is confirmed also by the displaced values expressed by the ratios with reference to the maximum, minimum and average values, summarised in Table 13, for each of the categories of recommendations.

Table 13. Maximum, minimum and average values of the TP/P ratio for each recommendation category

\begin{tabular}{lccc}
\hline & Positive & Neutral & Negative \\
\hline Maximum TP/P ratio & $209 \%$ & $142 \%$ & $113 \%$ \\
Minimum TP/P ratio & $-48 \%$ & $-57 \%$ & $-79 \%$ \\
Average TP/P ratio & $23 \%$ & $7 \%$ & $-11 \%$ \\
\hline
\end{tabular}

From table 14 in the appendix, which shows the degree of reliability of the target price and TP/P ratio on the basis of the industry, it emerges that the equities which on average have more optimistic target prices were those belonging to the Telecommunication Services, Financial, Industrials and Materials.

It has been already underlined above (Table 6 - Panel $C$ - in the appendix) that the Industrials, Telecommunication Services and Materials sector received the highest percentage of positive recommendations among the industries represented within the Ftse Mib stock market.

\subsection{Analysis on the Market of Informative "Brokers"}

The purpose of this latter analysis is to single out the information on the quality of equity research for each brokerage house that has issued reports on the 40 companies of the Ftse Mib stock index over the considered period.

In this way, it should be possible to develop a kind of "quality index" for each brokerage house.

Table 15 in the appendix, lists the intermediaries (93) that have been active in equity research during the examined period. The table enables to distinguish the nationality of the brokers, classified as Italian (I) - 9 - or Foreigner (F)-84, the overall number of the reports and what type of information they contain: recommendation, target price, both, the expected target price and the actual target price confirming the forecast without and with the use of the 5\% discretion interval.

The first peculiarity emerging after quickly browsing through the data, is that corporate reports are released by a large number of brokers, but the large number of reports are concentrated on a small number of brokers. This might indicate that a kind of specialization is created within Equity Research, dictated by the fact that a higher productivity should consequently also result in a certain degree of market recognition, both among competitors as well as investors. However, this hypothesis should be verified.

It is particularly useful to estimate the forecasts accuracy, to analyse the data on the reliability of the target prices issued by each financial intermediary. Target price reliability, in fact, is not disclosed in any way, unlike the percentages on the composition of the issued recommendations that are disclosed by the Brokers themselves. 
As stated earlier, if it was not possible to estimate the actual target price accuracy on behalf of the investors, whether they are actual or only potential clients, then the analysts themselves would be less inclined to produce accurate analyses as the reputational risk would be very limited if not absent.

The results obtained with regard to the reliability degree of the forecasts provided by financial intermediaries also allow to understand whether it is possible to apply the economies of scale theory to equity research.

If this was possible, a high level of forecast accuracy should be observed for brokers producing the largest number of corporate reports.

Data in Table 15 show higher percentages of reached target prices for brokers issuing more reports than the least prolific ones, even if they are still unsatisfactory.

In addition, by observing table 16, it emerges that the 5 intermediaries that produced the largest number of corporate reports containing a target price reach percentages of forecasts accuracy which are over the average. The only exceptions are represented by Banca IMI, which however reveal to be able to deliver reliable target prices in the 5\% discretion interval. This means that a sharp curve of learning is highlighted.

Table 16. Data on the accuracy of target prices expressed by the five top brokers for the number of issued reports

\begin{tabular}{lccccc}
\hline Equity & Target Price & \multicolumn{2}{c}{ Reached TP } & \multicolumn{2}{c}{$+/$ - 5\% Reached TP } \\
& $N^{\circ}$ & $N^{\circ}$ & $\%$ & $N^{\circ}$ & $\%$ \\
\hline Equita SIM SpA & 623 & 397 & $63.7 \%$ & 458 & $73.5 \%$ \\
Banca Akros (ESN) & 611 & 362 & $59.2 \%$ & 398 & $65.1 \%$ \\
Mediobanca SpA & 598 & 320 & $53.5 \%$ & 377 & $63.0 \%$ \\
Kepler Cheuvreux & 562 & 336 & $59.8 \%$ & 397 & $70.6 \%$ \\
Banca IMI & 536 & 292 & $54.5 \%$ & 361 & $67.4 \%$ \\
\hline
\end{tabular}

For the sake of completeness, the above considerations at aggregate level have been repeated also with reference to the activity of each single intermediary, confirming both the widespread optimism about the market trends and the relative intermediaries ability to formulate accurate recommendations and target prices. This information is contained in table 17, which is reported in the appendix.

One last element to consider in the informative brokers market analysis is the analysts' origin, whether they are Italian or Foreigner, in order to understand whether the activity on the home market may or may not be an important component for developing the ability to produce more selective analyses and more accurate predictions.

Only 9 brokers out of 93 which were active in research during the period observed were Italian.

Looking at the data in Table 18, reported here below, it can be noticed that activity in the home market is quite irrelevant to the ability to produce more accurate predictions.

Table 18. National and international brokers data on the accuracy of the Target Price

\begin{tabular}{lcccccccc}
\hline \multirow{2}{*}{ Nationality } & \multicolumn{2}{c}{ Brokers } & \multicolumn{2}{c}{ Reports } & Target Price & \multicolumn{2}{c}{ Reached TP } & \multicolumn{2}{c}{$+/ 5 \%$ Reached TP } \\
\cline { 2 - 8 } & $N^{\circ}$ & $N^{\circ}$ & $\%$ & $N^{\circ}$ & $N^{\circ}$ & $\%$ & $N^{\circ}$ & $\%$ \\
\hline Italian & 9 & 2961 & $26.2 \%$ & 2795 & 1633 & $58.4 \%$ & 1887 & $67.5 \%$ \\
Foreigner & 84 & 8361 & $73.8 \%$ & 7495 & 4137 & $55.2 \%$ & 4892 & $65.3 \%$ \\
Total & 93 & 11322 & $100 \%$ & 10290 & 5770 & $56.1 \%$ & 6779 & $65.9 \%$ \\
\hline
\end{tabular}

\section{Concluding Remarks}

The analysis presented in this paper was intended to explain both the composition of the Italian equity research system and the ability of analysts to properly assess the fair value of the equities under study, in order to test their reliability degree and detect possible anomalies in the recommendations for the investors.

The original of the complete analysis about the equity research carried out on the reports issued on companies belonging to the FtseMib stock index during a period of 5 years, has ended up highlighting a highly fragmented context which is hard to measure in terms of quality.

Even if financial intermediaries' ability to make forecasts on equities' future performance has been recognized as 
superior to the average, also thanks to more in-depth and accurate information they have access to, it has surely emerged that they do not excel in the reached results, highlighting the limits of the methods of analysis used in the field of equity research.

In any way, some remarkable consideration can underline the peculiarity of the Italian equity research system.

First at all, the high number of the reports (11322 in 5 years, with an annual increase every year (Note 5) seems to confirm that the average of analysts' forecasts is to be considered key in building the so-called "market consensus forecast", no matter how they are collected or their degree of reliability. As may be expected, this factor plays an important role in relation to the price of listed securities, since it affects its trend and determines a status of trading hegemony. If analysts improve their forecasts on the future performance of a given company, the price of its stock often takes advantage of positive consequences, adapting to new expectations. In fact, these indicators come from subjects that are institutionally informed and that, from a professional point of view, are in charge of the process of informative evaluation; their analyses are thus recognized by the market to contain results expressing actual reference values. And in our results the analysis present more than $40 \%$ positive recommendations and only $17.1 \%$ suggest negative valuations.

A second interesting consideration, remarks that these recommendations can be generally classified in three macro categories (buy, neutral and sell, as already explained), although the evaluations used are actually much more articulated (as shown in table 5). The terminology adopted for the indications as well as the number of judgments in the scale of values are different for every broker. This makes it more difficult to compare recommendations issued by different intermediaries, as was be shown by empirical evidence examined in this paper. In several highly frequent cases, some reports were issued by more than a broker on the same day and, though containing the same target price, they included significantly different recommendations, introducing therefore an aspect of evaluative "opacity" in communication to the market.

So, in the light of the above, if, on the one hand, it would be desirable for all companies to use an evaluation scale and a shared rating system-in view of information rationalization-aimed at better judgment transparency for customers, on the other the question arises about the interpretative aim of differentiation on the part of "proponent" intermediaries. A possible interpretation may attach not only a peculiar stylistic value to this differentiation in terms, but also the distinctive character typical of a variable aimed at distinguishing, and therefore drawing the attention to, a specific report-broker, that is to say a sort of "identification mark" offered to the market.

The nature and the level of the "identification mark" of the activity of financial analysts, because of its physiologically public nature (to the extent that it could be defined a "public good" in terms of the information produced) (Anolli-Banfi-Presti-Rescigno, 2007), however are implicitly affected by problems related to its remuneration. To begin with, this limit can be seen in its immediate form, that is to say when to the result of the analysis does not correspond any order execution, and therefore no immediate operating profit is achieved by the "author" of the evaluation taking advantage of related market investment/disinvestment (obviously, this is also publicly and officially prohibited by the regulation itself) (Bonini-Zanetti-Bianchini-Salvi, 2010). Furthermore, the same limit can also be found in the actual and substantial impossibility to prevent those who have not paid for the research from accessing the results: when report information becomes public (and it wants to be public)-thus when all market actors can access it-the duplication effect becomes in fact a self-produced consequence, with a higher level of "precision" (conformity to suggestions), the more the analyses are considered to be reliable (Fusconi, 1999).

On the other hand, it must be remembered that, being the uptake rate (and therefore the ability to adapt one's values to all available information promptly) an intrinsic characteristic to measure the degree of efficiency of financial tools markets, it makes also the product of analysts' activity rapidly obsolete after its first commercialization, making it, in turn, even more difficult to find a sufficient demand to support an efficient supply level.

As can easily be imagined, the non self-supporting feature of research described above and, therefore, the need for subsidy through more profitable business have inevitably influenced (potentially still nowadays) the ways in which analysts' activity is undertaken and distributed on the market, and have consequently undermined its "natural" autonomy and freedom from pressures on evaluations. Only a limited number of analysts do work without an employment or association relationship with other professional operators (and can thus be termed "independent"), and make a profit from directly selling the results of their studies to customers, private or institutional investors, as shown in table 17.

Part of the research is developed on behalf of institutional investors, who, thanks to their portfolios, can recover the costs incurred through the immediate use of "first-hand" information (namely, information that has not been incorporated in the prices of securities yet) on the secondary market. Single investors and other market operators who do not purchase this financial advice directly (because of their limited size or else) can only rely on the 
investment recommendations issued by the research departments of the most structured financial intermediaries, so as to exploit the marginal effects of public information that are still "available" after its absorption in the price, through the duplication of operational orders, and in any case hoping that the issuer be reliable, as already mentioned above.

In the activity of sell-side analysts, especially those belonging to polyfunctional intermediaries, judgments characterized by excessive optimism or repeatedly optimistic recommendations (as it is believed that the ability to attract, and therefore move, market interests can be pursued also by resorting more frequently to advertisements containing converging, if not explicitly repetitive, indications, aimed at urging investors to take an effective position in the market) can be explained as incentives aimed at (1) finding or retaining important customers managed by the investment banking activity, in order to obtain a higher economic return from trading commissions, or at (2) "correcting"-by making it positive - the value of the same intermediary's property portfolio.

The reaction of share prices to recommendations and target prices in corporate reports can in effect trigger a conflict of interest for the intermediary, between equity research activity and proprietary trading activity, as concerted actions between these units could result in large capital gains for merchant banks.

It is, however, true that, if the regulatory authority considers the presence of Chinese walls a sufficient condition, the conflictive relationship is not completely implicit (CESR, 2002); or rather, it seems to be implicitly accepted by the legislative body through the imposition of criteria in structural organization (Chinese walls), transparency, clarity and accuracy in informative communication.

But even accepting the hypothesis of all these possible conflicts of interest, the "ability" is not so evident in the market: the results in table 18 underline that equity research reached Target Price only for $58 \%$ of the Italian intermediaries reports and for 55.2\% in case of Foreign intermediaries studies. With these results we can accept to supports the so-called "no-conflict hypothesis" (De Vincentiis, 2010), according to which analysts' forecast errors are due to the intrinsic difficulty of this activity, rather than to existing conflicts of interest, although researches show excessive optimism.

The analyst's recommendations and target prices are therefore influenced by the past performance of the index, while it would be desirable, as stated above, that a financial analyst focused on identifying the fire price of a stock in order to suggest an effective strategy rather than a strategy that adapts to markets trends.

\section{References}

Anolli, M., Banfi, A., Presti, G., \& Rescigno, M. (2007). Banche, Servizi Di Investimento E Conflitti Di Interesse. Bologna: Il Mulino.

Asquith, P., Mikhail, M.B., \& Au, A.S. (2005). Information Content of Equity Analyst Reports. Journal of Financial Economics, 75(1), 245-282. https://doi.org/10.1016/j.jfineco.2004.01.002

Barber, B., Lehavy, R., \& Trueman, B. (2007, August). Comparing the stock recommendation performance of investment banks and independent research firms. Journal of Financial Economics, 84(2), 490-517. https://doi.org/10.1016/j.jfineco.2005.09.004

Belcredi, M., Bozzi, S., \& Rigamonti, S. (2003). The impact of research reports on stock prices in Italy. Retrieved from http://www.efmaefm.org

Bonini, S., Zanetti, L., Bianchini, R., \& Salvi, A. (2010). Target Price Accuracy in Equity Research. Journal of Business Finance \& Accounting, 37(9-10), 1177-1217. https://doi.org/10.1111/j.1468-5957.2010.02209.x

Bradshaw, M.T., \& Brown, L.D. (2006). Do Sell-Side Analysts Exhibit Differential Target Price Forecasting Ability?. Harvard Business School \& Georgia State University. Working Paper.

Brav, A., \& Leahvy, R. (2003). An Empirical Analysis of Analysts' Target Prices: Short-Term Informativeness and Long-term Dynamics. The Journal of Finance, 58(5), 1933-1967. https://doi.org/10.1111/1540-6261.00593

Cervellati, E.M., Della Bina, A.C.F., \& Pattitoni, P. (2008). The efficiency of the Italian stock exchange: market reaction following changes in recommendations. Corporate Ownership \& Control, 5(2), Winter, 432-448. https://doi.org/10.22495/cocv5i2c4p5

CESR-The Committee of European Securities Regulators. (2002, February). Measures to promote market integrity. Retrievd from www.esma.europa.eu

De Vincentiis, P. (2010). Accuratezza e distorsione delle previsioni degli analisti finanziari in un contesto di elevata trasparenza. Una verifica empirica del mercato italiano. Bancaria, 66(3), 31-51. 
Fama, E. (1970) Efficient capital markets a review of theory and empirical works. Journal of Finance, 25(2), 383-417. https://doi.org/10.2307/2325486

Fandella, P. (2012). Il sistema informative e I mercati degli strumenti finanziari. Un'analisi del grado di efficienza qualitativa nel mercato italiano. Milano: Vita e Pensiero.

Francis, J., \& Soffer, L. (1997). The Relative Informativeness of Analysts' Stock Reccomendations and Earnings Forecast Revisions. Journal of Accounting Research, 35(2), 193-211. https://doi.org/10.2307/2491360

Fusconi, A. (1999). Economia e struttura dei mercati degli strumenti finanziari. Torino: Giappichelli Editore.

Fusconi, A. (2010). L'informazione come Valore. Lezioni di Economia del Mercato Mobiliare. Milano: Vita e Pensiero.

Jensen, M.C. (2004). Agency Costs of Overvalued Equity. Financial Management, 34(1), 5-19.

Johnson, J. (2006, June). The Future of Equity Research: A $360^{\circ}$ Prospective. Retrieved from www.tabbgroup.org

Womack, L. (1996). Do brokerage analysts' recommendations have investment value?. Journal of Finance, 51, 137-167. https://doi.org/10.1111/j.1540-6261.1996.tb05205.x

\section{Appendix}

Table 3. Reports total breakdown per recommendation/target price by month (absolute and percentage value)

\begin{tabular}{|c|c|c|c|c|c|c|}
\hline \multirow{2}{*}{ Months } & \multirow{2}{*}{ Years } & \multirow{2}{*}{ Reports } & \multicolumn{2}{|c|}{ Recomandations } & \multicolumn{2}{|c|}{ Target Price } \\
\hline & & & $N^{\circ}$ & $\%$ & $N^{\circ}$ & $\%$ \\
\hline 12 & 2016 & 349 & 346 & $99,1 \%$ & 322 & $92,3 \%$ \\
\hline 11 & 2016 & 268 & 267 & $99,6 \%$ & 249 & $92,9 \%$ \\
\hline 10 & 2016 & 49 & 49 & $100,0 \%$ & 45 & $91,8 \%$ \\
\hline 9 & 2016 & 346 & 345 & $99,7 \%$ & 324 & $93,6 \%$ \\
\hline 8 & 2016 & 167 & 166 & $99,4 \%$ & 148 & $88,6 \%$ \\
\hline 7 & 2016 & 117 & 117 & $100,0 \%$ & 110 & $94,0 \%$ \\
\hline 6 & 2016 & 373 & 369 & $98,9 \%$ & 341 & $91,4 \%$ \\
\hline 5 & 2016 & 211 & 210 & $99,5 \%$ & 193 & $91,5 \%$ \\
\hline 4 & 2016 & 55 & 55 & $100,0 \%$ & 44 & $80,0 \%$ \\
\hline 3 & 2016 & 460 & 456 & $99,1 \%$ & 425 & $92,4 \%$ \\
\hline 2 & 2016 & 146 & 144 & $98,6 \%$ & 130 & $89,0 \%$ \\
\hline 1 & 2016 & 52 & 52 & $100,0 \%$ & 48 & $92,3 \%$ \\
\hline 12 & 2015 & 299 & 297 & $99,3 \%$ & 278 & $93,0 \%$ \\
\hline 11 & 2015 & 229 & 228 & $99,6 \%$ & 214 & $93,4 \%$ \\
\hline 10 & 2015 & 72 & 69 & $95,8 \%$ & 62 & $86,1 \%$ \\
\hline 9 & 2015 & 325 & 323 & $99,4 \%$ & 308 & $94,8 \%$ \\
\hline 8 & 2015 & 154 & 154 & $100,0 \%$ & 139 & $90,3 \%$ \\
\hline 7 & 2015 & 116 & 115 & $99,1 \%$ & 106 & $91,4 \%$ \\
\hline 6 & 2015 & 312 & 307 & $98,4 \%$ & 294 & $94,2 \%$ \\
\hline 5 & 2015 & 263 & 263 & $100,0 \%$ & 229 & $87,1 \%$ \\
\hline 4 & 2015 & 51 & 50 & $98,0 \%$ & 41 & $80,4 \%$ \\
\hline 3 & 2015 & 452 & 448 & $99,1 \%$ & 413 & $91,4 \%$ \\
\hline 2 & 2015 & 144 & 141 & $97,9 \%$ & 129 & $89,6 \%$ \\
\hline 1 & 2015 & 34 & 33 & $97,1 \%$ & 28 & $82,4 \%$ \\
\hline 12 & 2014 & 324 & 318 & $98,1 \%$ & 295 & $91,0 \%$ \\
\hline 11 & 2014 & 216 & 215 & $99,5 \%$ & 193 & $89,4 \%$ \\
\hline 10 & 2014 & 51 & 51 & $100,0 \%$ & 43 & $84,3 \%$ \\
\hline 9 & 2014 & 310 & 305 & $98,4 \%$ & 289 & $93,2 \%$ \\
\hline 8 & 2014 & 183 & 183 & $100,0 \%$ & 158 & $86,3 \%$ \\
\hline 7 & 2014 & 59 & 59 & $100,0 \%$ & 56 & $94,9 \%$ \\
\hline 6 & 2014 & 260 & 256 & $98,5 \%$ & 238 & $91,5 \%$ \\
\hline 5 & 2014 & 225 & 224 & $99,6 \%$ & 200 & $88,9 \%$ \\
\hline 4 & 2014 & 69 & 69 & $100,0 \%$ & 50 & $72,5 \%$ \\
\hline 3 & 2014 & 414 & 410 & $99,0 \%$ & 368 & $88,9 \%$ \\
\hline 2 & 2014 & 106 & 105 & $99,1 \%$ & 102 & $96,2 \%$ \\
\hline 1 & 2014 & 56 & 50 & $89,3 \%$ & 44 & $78,6 \%$ \\
\hline 12 & 2013 & 222 & 217 & $97,7 \%$ & 203 & $91,4 \%$ \\
\hline 11 & 2013 & 226 & 225 & $99,6 \%$ & 206 & $91,2 \%$ \\
\hline 10 & 2013 & 66 & 66 & $100,0 \%$ & 53 & $80,3 \%$ \\
\hline 9 & 2013 & 260 & 256 & $98,5 \%$ & 239 & $91,9 \%$ \\
\hline 8 & 2013 & 151 & 149 & $98,7 \%$ & 141 & $93,4 \%$ \\
\hline 7 & 2013 & 69 & 69 & $100,0 \%$ & 64 & $92,8 \%$ \\
\hline 6 & 2013 & 250 & 248 & $99,2 \%$ & 212 & $84,8 \%$ \\
\hline 5 & 2013 & 184 & 183 & $99,5 \%$ & 177 & $96,2 \%$ \\
\hline 4 & 2013 & 47 & 41 & $87,2 \%$ & 39 & $83,0 \%$ \\
\hline 3 & 2013 & 359 & 355 & $98,9 \%$ & 337 & $93,9 \%$ \\
\hline 2 & 2013 & 100 & 99 & $99,0 \%$ & 95 & $95,0 \%$ \\
\hline 1 & 2013 & 72 & 69 & $95,8 \%$ & 47 & $65,3 \%$ \\
\hline 12 & 2012 & 209 & 205 & $98,1 \%$ & 201 & $96,2 \%$ \\
\hline 11 & 2012 & 198 & 198 & $100,0 \%$ & 179 & $90,4 \%$ \\
\hline 10 & 2012 & 45 & 44 & $97,8 \%$ & 42 & $93,3 \%$ \\
\hline 9 & 2012 & 269 & 265 & $98,5 \%$ & 244 & $90,7 \%$ \\
\hline 8 & 2012 & 171 & 168 & $98,2 \%$ & 154 & $90,1 \%$ \\
\hline 7 & 2012 & 64 & 63 & $98,4 \%$ & 62 & $96,9 \%$ \\
\hline 6 & 2012 & 223 & 217 & $97,3 \%$ & 204 & $91,5 \%$ \\
\hline 5 & 2012 & 208 & 205 & $98,6 \%$ & 192 & $92,3 \%$ \\
\hline 4 & 2012 & 58 & 56 & $96,6 \%$ & 48 & $82,8 \%$ \\
\hline 3 & 2012 & 431 & 422 & $97,9 \%$ & 384 & $89,1 \%$ \\
\hline 2 & 2012 & 92 & 92 & $100,0 \%$ & 89 & $96,7 \%$ \\
\hline 1 & 2012 & 31 & 29 & $93,5 \%$ & 22 & $71,0 \%$ \\
\hline & & 11322 & 11190 & 98,8 & 10290 & $90,9 \%$ \\
\hline
\end{tabular}


Table 4 (Panel A). Detail of the number of reports by equity and relative information

\begin{tabular}{|c|c|c|c|c|c|}
\hline \multirow{2}{*}{ Name } & \multirow{2}{*}{$\begin{array}{c}\text { Number of } \\
\text { Report }\end{array}$} & \multicolumn{2}{|c|}{ Not Rated } & \multicolumn{2}{|c|}{ Rated } \\
\hline & & $N^{\circ}$ & $\%$ & $N^{\circ}$ & $\%$ \\
\hline ENI SPA & 627 & 15 & $2,40 \%$ & 612 & $97,60 \%$ \\
\hline ENEL SPA & 528 & 3 & $0,60 \%$ & 525 & $99,40 \%$ \\
\hline INTESA SANPAOLO & 584 & 0 & $0,00 \%$ & 584 & $100,00 \%$ \\
\hline UNICREDIT SPA & 631 & 2 & $0,30 \%$ & 629 & $99,70 \%$ \\
\hline ASSICURAZIONI GENERALI & 562 & 6 & $1,10 \%$ & 556 & $98,90 \%$ \\
\hline ATLANTIA SPA & 351 & 3 & $0,90 \%$ & 348 & $99,10 \%$ \\
\hline FIAT CHRYSLER AUTOMOBILES NV & 222 & 1 & $0,50 \%$ & 221 & $99,50 \%$ \\
\hline SNAM SPA & 391 & 1 & $0,30 \%$ & 390 & $99,70 \%$ \\
\hline TELECOM ITALIA SPA & 579 & 39 & $6,70 \%$ & 540 & $93,30 \%$ \\
\hline FERRARI NV & 62 & 0 & $0,00 \%$ & 62 & $100,00 \%$ \\
\hline CNH INDUSTRIAL NV & 229 & 2 & $0,90 \%$ & 227 & $99,10 \%$ \\
\hline STMICROELECTRONICS NV & 346 & 0 & $0,00 \%$ & 346 & $100,00 \%$ \\
\hline LUXOTTICA GROUP SPA & 377 & 1 & $0,30 \%$ & 376 & $99,70 \%$ \\
\hline TERNA SPA & 332 & 0 & $0,00 \%$ & 332 & $100,00 \%$ \\
\hline TENARIS SA & 269 & 0 & $0,00 \%$ & 269 & $100,00 \%$ \\
\hline EXOR NV & 78 & 1 & $1,30 \%$ & 77 & $98,70 \%$ \\
\hline LEONARDO SPA & 275 & 1 & $0,40 \%$ & 274 & $99,60 \%$ \\
\hline PRYSMIAN SPA & 317 & 0 & $0,00 \%$ & 317 & $100,00 \%$ \\
\hline MEDIOBANCA SPA & 215 & 0 & $0,00 \%$ & 215 & $100,00 \%$ \\
\hline BANCO BPM SPA & 312 & 6 & $1,90 \%$ & 306 & $98,10 \%$ \\
\hline MONCLER SPA & 188 & 0 & $0,00 \%$ & 188 & $100,00 \%$ \\
\hline RECORDATI SPA & 130 & 0 & $0,00 \%$ & 130 & $100,00 \%$ \\
\hline UBI BANCA SPA & 330 & 0 & $0,00 \%$ & 330 & $100,00 \%$ \\
\hline DAVIDE CAMPARI-MILANO SPA & 327 & 0 & $0,00 \%$ & 327 & $100,00 \%$ \\
\hline POSTE ITALIANE SPA & 48 & 0 & $0,00 \%$ & 48 & $100,00 \%$ \\
\hline FINECOBANK SPA & 65 & 0 & $0,00 \%$ & 65 & $100,00 \%$ \\
\hline BPER BANCA & 180 & 0 & $0,00 \%$ & 180 & $100,00 \%$ \\
\hline SAIPEM SPA & 494 & 7 & $1,40 \%$ & 487 & $98,60 \%$ \\
\hline UNIPOLSAI ASSICURAZIONI SPA & 144 & 13 & $9,00 \%$ & 131 & $91,00 \%$ \\
\hline A2A SPA & 179 & 1 & $0,60 \%$ & 178 & $99,40 \%$ \\
\hline ITALGAS SPA & 16 & 0 & $0,00 \%$ & 16 & $100,00 \%$ \\
\hline AZIMUT HOLDING SPA & 152 & 3 & $2,00 \%$ & 149 & $98,00 \%$ \\
\hline UNIPOL GRUPPO FINANZIARIO SP & 149 & 10 & $6,70 \%$ & 139 & $93,30 \%$ \\
\hline BREMBO SPA & 180 & 0 & $0,00 \%$ & 180 & $100,00 \%$ \\
\hline SALVATORE FERRAGAMO SPA & 357 & 0 & $0,00 \%$ & 357 & $100,00 \%$ \\
\hline BANCA MEDIOLANUM SPA & 28 & 0 & $0,00 \%$ & 28 & $100,00 \%$ \\
\hline BUZZI UNICEM SPA & 323 & 0 & $0,00 \%$ & 323 & $100,00 \%$ \\
\hline BANCA GENERALI SPA & 153 & 9 & $5,90 \%$ & 144 & $94,10 \%$ \\
\hline YOOX NET-A-PORTER GROUP & 173 & 2 & $1,20 \%$ & 171 & $98,80 \%$ \\
\hline MEDIASET SPA & 419 & 6 & $1,40 \%$ & 413 & $98,60 \%$ \\
\hline Total & 11322 & 132 & $1,20 \%$ & 11190 & $98,80 \%$ \\
\hline
\end{tabular}

This table reports data concerning the number of reports issued in the period under analysis by equity as well as the relative recommendations and explicit target prices.

Table 4 (Panel B). Detail on the number of reports by sector and relative information

\begin{tabular}{|c|c|c|c|c|c|}
\hline \multirow{2}{*}{ Sector } & \multirow{2}{*}{$\begin{array}{c}\text { Number of } \\
\text { Report }\end{array}$} & \multicolumn{2}{|c|}{ Not Rated } & \multicolumn{2}{|c|}{ Rated } \\
\hline & & $N^{\circ}$ & $\%$ & $N^{\circ}$ & $\%$ \\
\hline Consumer Discretionary & 1978 & 10 & $0,50 \%$ & 1968 & $99,50 \%$ \\
\hline Consumer Staples & 327 & 0 & $0,00 \%$ & 327 & $100,00 \%$ \\
\hline Energy & 1781 & 23 & $1,30 \%$ & 1758 & $98,70 \%$ \\
\hline Financials & 3631 & 50 & $1,40 \%$ & 3581 & $98,60 \%$ \\
\hline Health Care & 130 & 0 & $0,00 \%$ & 130 & $100,00 \%$ \\
\hline Industrials & 1172 & 6 & $0,50 \%$ & 1166 & $99,50 \%$ \\
\hline Information Technology & 346 & 0 & $0,00 \%$ & 346 & $100,00 \%$ \\
\hline Materials & 323 & 0 & $0,00 \%$ & 323 & $100,00 \%$ \\
\hline Telecommunication Services & 579 & 39 & $6,70 \%$ & 540 & $93,30 \%$ \\
\hline Utilities & 1055 & 4 & $0,40 \%$ & 1051 & $99,60 \%$ \\
\hline Total & 11322 & 132 & $1,20 \%$ & 11190 & $98,80 \%$ \\
\hline
\end{tabular}


Table 4 (Panel C). Detail of the number of report by industry and relative information

\begin{tabular}{|c|c|c|c|c|c|c|}
\hline \multirow{2}{*}{ Sector } & \multirow{2}{*}{ Industry } & \multirow{2}{*}{$\begin{array}{c}\text { Number of } \\
\text { Report }\end{array}$} & \multicolumn{2}{|c|}{ Not Rated } & \multicolumn{2}{|c|}{ Rated } \\
\hline & & & $N^{\circ}$ & $\%$ & $N^{\circ}$ & $\%$ \\
\hline Consumer Discretionary & Automobiles & 284 & 1 & $0,40 \%$ & 283 & $99,60 \%$ \\
\hline Consumer Discretionary & Textiles, Apparel \& Luxury Goo & 922 & 1 & $0,10 \%$ & 921 & $99,90 \%$ \\
\hline Consumer Discretionary & Auto Components & 180 & 0 & $0,00 \%$ & 180 & $100,00 \%$ \\
\hline Consumer Discretionary & Internet \& Direct Marketing Re & 173 & 2 & $1,20 \%$ & 171 & $98,80 \%$ \\
\hline Consumer Discretionary & Media & 419 & 6 & $1,40 \%$ & 413 & $98,60 \%$ \\
\hline Consumer Staples & Beverages & 327 & 0 & $0,00 \%$ & 327 & $100,00 \%$ \\
\hline Energy & Oil, Gas \& Consumable Fuels & 1018 & 16 & $1,60 \%$ & 1002 & $98,40 \%$ \\
\hline Energy & Energy Equipment \& Services & 763 & 7 & $0,90 \%$ & 756 & $99,10 \%$ \\
\hline Financials & Banks & 2317 & 8 & $0,30 \%$ & 2309 & $99,70 \%$ \\
\hline Financials & Insurance & 903 & 29 & $3,20 \%$ & 874 & $96,80 \%$ \\
\hline Financials & Diversified Financial Services & 106 & 1 & $0,90 \%$ & 105 & $99,10 \%$ \\
\hline Financials & Capital Markets & 305 & 12 & $3,90 \%$ & 293 & $96,10 \%$ \\
\hline Health Care & Pharmaceuticals & 130 & 0 & $0,00 \%$ & 130 & $100,00 \%$ \\
\hline Industrials & Transportation Infrastructure & 351 & 3 & $0,90 \%$ & 348 & $99,10 \%$ \\
\hline Industrials & Machinery & 229 & 2 & $0,90 \%$ & 227 & $99,10 \%$ \\
\hline Industrials & Aerospace \& Defense & 275 & 1 & $0,40 \%$ & 274 & $99,60 \%$ \\
\hline Industrials & Electrical Equipment & 317 & 0 & $0,00 \%$ & 317 & $100,00 \%$ \\
\hline Information Technology & Semiconductors \& Semiconductor & 346 & 0 & $0,00 \%$ & 346 & $100,00 \%$ \\
\hline Materials & Construction Materials & 323 & 0 & $0,00 \%$ & 323 & $100,00 \%$ \\
\hline Telecommunication Services & Diversified Telecommunication & 579 & 39 & $6,70 \%$ & 540 & $93,30 \%$ \\
\hline Utilities & Electric Utilities & 860 & 3 & $0,30 \%$ & 857 & $99,70 \%$ \\
\hline Utilities & Multi-Utilities & 179 & 1 & $0,60 \%$ & 178 & $99,40 \%$ \\
\hline \multirow[t]{2}{*}{ Utilities } & Gas Utilities & 16 & 0 & $0,00 \%$ & 16 & $100,00 \%$ \\
\hline & Total & 11322 & 132 & $1,20 \%$ & 11190 & $98,80 \%$ \\
\hline
\end{tabular}

This table reports data concerning the number of reports issued in the period under analysis by industry an as well as the relative recommendations and explicit target prices 
Table 6 (Panel B). Detail of recommendations by equity

\begin{tabular}{|c|c|c|c|c|c|c|c|c|c|c|c|}
\hline \multirow{2}{*}{ Name } & \multirow{2}{*}{\begin{tabular}{|c|} 
Number of \\
Report
\end{tabular}} & \multicolumn{2}{|c|}{ Not Rated } & \multicolumn{2}{|c|}{ Rated } & \multicolumn{2}{|c|}{$B U Y$} & \multicolumn{2}{|c|}{ NEUTRAL } & \multicolumn{2}{|c|}{ SELL } \\
\hline & & $N^{\circ}$ & $\%$ & $N^{\circ}$ & $\%$ & $N^{\circ}$ & $\%$ & $N^{\circ}$ & $\%$ & $N^{\circ}$ & $\%$ \\
\hline ENI SPA & 627 & 15 & $2,40 \%$ & 612 & $97,60 \%$ & 248 & $40,50 \%$ & 259 & $42,30 \%$ & 105 & $17,20 \%$ \\
\hline ENEL SPA & 528 & 3 & $0,60 \%$ & 525 & $99,40 \%$ & 252 & $48,00 \%$ & 215 & $41,00 \%$ & 58 & $11,00 \%$ \\
\hline INTESA SANPAOLO & 584 & 0 & $0,00 \%$ & 584 & $100,00 \%$ & 264 & $45,20 \%$ & 221 & $37,80 \%$ & 99 & $17,00 \%$ \\
\hline UNICREDIT SPA & 631 & 2 & $0,30 \%$ & 629 & $99,70 \%$ & 233 & $37,00 \%$ & 263 & $41,80 \%$ & 133 & $21,10 \%$ \\
\hline ASSICURAZIONI GENERALI & 562 & 6 & $1,10 \%$ & 556 & $98,90 \%$ & 159 & $28,60 \%$ & 242 & $43,50 \%$ & 155 & $27,90 \%$ \\
\hline ATLANTIA SPA & 351 & 3 & $0,90 \%$ & 348 & $99,10 \%$ & 232 & $66,70 \%$ & 93 & $26,70 \%$ & 23 & $6,60 \%$ \\
\hline FIAT CHRYSLER AUTOMOBILES NV & 222 & 1 & $0,50 \%$ & 221 & $99,50 \%$ & 104 & $47,10 \%$ & 69 & $31,20 \%$ & 48 & $21,70 \%$ \\
\hline SNAM SPA & 391 & 1 & $0,30 \%$ & 390 & $99,70 \%$ & 179 & $45,90 \%$ & 182 & $46,70 \%$ & 29 & $7,40 \%$ \\
\hline TELECOM ITALIA SPA & 579 & 39 & $6,70 \%$ & 540 & $93,30 \%$ & 262 & $48,50 \%$ & 224 & $41,50 \%$ & 54 & $10,00 \%$ \\
\hline FERRARI NV & 62 & 0 & $0,00 \%$ & 62 & $100,00 \%$ & 35 & $56,50 \%$ & 11 & $17,70 \%$ & 16 & $25,80 \%$ \\
\hline CNH INDUSTRIAL NV & 229 & 2 & $0,90 \%$ & 227 & $99,10 \%$ & 67 & $29,50 \%$ & 114 & $50,20 \%$ & 46 & $20,30 \%$ \\
\hline STMICROELECTRONICS NV & 346 & 0 & $0,00 \%$ & 346 & $100,00 \%$ & 65 & $18,80 \%$ & 190 & $54,90 \%$ & 91 & $26,30 \%$ \\
\hline LUXOTTICA GROUP SPA & 377 & 1 & $0,30 \%$ & 376 & $99,70 \%$ & 140 & $37,20 \%$ & 169 & $44,90 \%$ & 67 & $17,80 \%$ \\
\hline TERNA SPA & 332 & 0 & $0,00 \%$ & 332 & $100,00 \%$ & 104 & $31,30 \%$ & 161 & $48,50 \%$ & 67 & $20,20 \%$ \\
\hline TENARIS SA & 269 & 0 & $0,00 \%$ & 269 & $100,00 \%$ & 72 & $26,80 \%$ & 108 & $40,10 \%$ & 89 & $33,10 \%$ \\
\hline EXOR NV & 78 & 1 & $1,30 \%$ & 77 & $98,70 \%$ & 23 & $29,90 \%$ & 51 & $66,20 \%$ & 3 & $3,90 \%$ \\
\hline LEONARDO SPA & 275 & 1 & $0,40 \%$ & 274 & $99,60 \%$ & 118 & $43,10 \%$ & 102 & $37,20 \%$ & 54 & $19,70 \%$ \\
\hline PRYSMIAN SPA & 317 & 0 & $0,00 \%$ & 317 & $100,00 \%$ & 206 & $65,00 \%$ & 97 & $30,60 \%$ & 14 & $4,40 \%$ \\
\hline MEDIOBANCA SPA & 215 & 0 & $0,00 \%$ & 215 & $100,00 \%$ & 117 & $54,40 \%$ & 88 & $40,90 \%$ & 10 & $4,70 \%$ \\
\hline BANCO BPM SPA & 312 & 6 & $1,90 \%$ & 306 & $98,10 \%$ & 89 & $29,10 \%$ & 157 & $51,30 \%$ & 60 & $19,60 \%$ \\
\hline MONCLER SPA & 188 & 0 & $0,00 \%$ & 188 & $100,00 \%$ & 125 & $66,50 \%$ & 53 & $28,20 \%$ & 10 & $5,30 \%$ \\
\hline RECORDATI SPA & 130 & 0 & $0,00 \%$ & 130 & $100,00 \%$ & 56 & $43,10 \%$ & 69 & $53,10 \%$ & 5 & $3,80 \%$ \\
\hline UBI BANCA SPA & 330 & 0 & $0,00 \%$ & 330 & $100,00 \%$ & 102 & $30,90 \%$ & 169 & $51,20 \%$ & 59 & $17,90 \%$ \\
\hline DAVIDE CAMPARI-MILANO SPA & 327 & 0 & $0,00 \%$ & 327 & $100,00 \%$ & 73 & $22,30 \%$ & 173 & $52,90 \%$ & 81 & $24,80 \%$ \\
\hline POSTE ITALIANE SPA & 48 & 0 & $0,00 \%$ & 48 & $100,00 \%$ & 29 & $60,40 \%$ & 18 & $37,50 \%$ & 1 & $2,10 \%$ \\
\hline FINECOBANK SPA & 65 & 0 & $0,00 \%$ & 65 & $100,00 \%$ & 34 & $52,30 \%$ & 25 & $38,50 \%$ & 6 & $9,20 \%$ \\
\hline BPER BANCA & 180 & 0 & $0,00 \%$ & 180 & $100,00 \%$ & 93 & $51,70 \%$ & 75 & $41,70 \%$ & 12 & $6,70 \%$ \\
\hline SAIPEM SPA & 494 & 7 & $1,40 \%$ & 487 & $98,60 \%$ & 124 & $25,50 \%$ & 235 & $48,30 \%$ & 128 & $26,30 \%$ \\
\hline UNIPOLSAI ASSICURAZIONI SPA & 144 & 13 & $9,00 \%$ & 131 & $91,00 \%$ & 54 & $41,20 \%$ & 55 & $42,00 \%$ & 22 & $16,80 \%$ \\
\hline A2A SPA & 179 & 1 & $0,60 \%$ & 178 & $99,40 \%$ & 91 & $51,10 \%$ & 66 & $37,10 \%$ & 21 & $11,80 \%$ \\
\hline ITALGAS SPA & 16 & 0 & $0,00 \%$ & 16 & $100,00 \%$ & 12 & $75,00 \%$ & 4 & $25,00 \%$ & 0 & $0,00 \%$ \\
\hline AZIMUT HOLDING SPA & 152 & 3 & $2,00 \%$ & 149 & $98,00 \%$ & 76 & $51,00 \%$ & 52 & $34,90 \%$ & 21 & $14,10 \%$ \\
\hline UNIPOL GRUPPO FINANZIARIO SP & 149 & 10 & $6,70 \%$ & 139 & $93,30 \%$ & 93 & $66,90 \%$ & 26 & $18,70 \%$ & 20 & $14,40 \%$ \\
\hline BREMBO SPA & 180 & 0 & $0,00 \%$ & 180 & $100,00 \%$ & 96 & $53,30 \%$ & 70 & $38,90 \%$ & 14 & $7,80 \%$ \\
\hline SALVATORE FERRAGAMO SPA & 357 & 0 & $0,00 \%$ & 357 & $100,00 \%$ & 94 & $26,30 \%$ & 217 & $60,80 \%$ & 46 & $12,90 \%$ \\
\hline BANCA MEDIOLANUM SPA & 28 & 0 & $0,00 \%$ & 28 & $100,00 \%$ & 16 & $57,10 \%$ & 10 & $35,70 \%$ & 2 & $7,10 \%$ \\
\hline BUZZI UNICEM SPA & 323 & 0 & $0,00 \%$ & 323 & $100,00 \%$ & 143 & $44,30 \%$ & 115 & $35,60 \%$ & 65 & $20,10 \%$ \\
\hline BANCA GENERALI SPA & 153 & 9 & $5,90 \%$ & 144 & $94,10 \%$ & 73 & $50,70 \%$ & 62 & $43,10 \%$ & 9 & $6,30 \%$ \\
\hline YOOX NET-A-PORTER GROUP & 173 & 2 & $1,20 \%$ & 171 & $98,80 \%$ & 93 & $54,40 \%$ & 51 & $29,80 \%$ & 27 & $15,80 \%$ \\
\hline MEDIASET SPA & 419 & 6 & $1,40 \%$ & 413 & $98,60 \%$ & 109 & $26,40 \%$ & 165 & $40,00 \%$ & 139 & $33,70 \%$ \\
\hline Total & 11322 & 132 & $1,20 \%$ & 11190 & $98,80 \%$ & 4555 & $40,70 \%$ & 4726 & $42,20 \%$ & 1909 & $17,10 \%$ \\
\hline
\end{tabular}

Table 6 (Panel C). Detail of recommendations by sector

\begin{tabular}{|c|c|c|c|c|c|c|c|c|c|c|c|}
\hline \multirow{2}{*}{ Sector } & \multirow{2}{*}{$\begin{array}{c}\text { Number of } \\
\text { Report }\end{array}$} & \multicolumn{2}{|c|}{ Not Rated } & \multicolumn{2}{|c|}{ Rated } & \multicolumn{2}{|c|}{ BUY } & \multicolumn{2}{|c|}{ NEUTRAL } & \multicolumn{2}{|c|}{ SELL } \\
\hline & & $N^{\circ}$ & $\%$ & $N^{\circ}$ & $\%$ & $N^{\circ}$ & $\%$ & $N^{\circ}$ & $\%$ & $N^{\circ}$ & $\%$ \\
\hline Consumer Discretionary & 1978 & 10 & $0,50 \%$ & 1968 & $99,50 \%$ & 796 & $40,40 \%$ & 805 & $40,90 \%$ & 367 & $18,60 \%$ \\
\hline Consumer Staples & 327 & 0 & $0,00 \%$ & 327 & $100,00 \%$ & 73 & $22,30 \%$ & 173 & $52,90 \%$ & 81 & $24,80 \%$ \\
\hline Energy & 1781 & 23 & $1,30 \%$ & 1758 & $98,70 \%$ & 623 & $35,40 \%$ & 784 & $44,60 \%$ & 351 & $20,00 \%$ \\
\hline Financials & 3631 & 50 & $1,40 \%$ & 3581 & $98,60 \%$ & 1455 & $40,60 \%$ & 1514 & $42,30 \%$ & 612 & $17,10 \%$ \\
\hline Health Care & 130 & 0 & $0,00 \%$ & 130 & $100,00 \%$ & 56 & $43,10 \%$ & 69 & $53,10 \%$ & 5 & $3,80 \%$ \\
\hline Industrials & 1172 & 6 & $0,50 \%$ & 1166 & $99,50 \%$ & 623 & $53,40 \%$ & 406 & $34,80 \%$ & 137 & $11,70 \%$ \\
\hline Information Technology & 346 & 0 & $0,00 \%$ & 346 & $100,00 \%$ & 65 & $18,80 \%$ & 190 & $54,90 \%$ & 91 & $26,30 \%$ \\
\hline Materials & 323 & 0 & $0,00 \%$ & 323 & $100,00 \%$ & 143 & $44,30 \%$ & 115 & $35,60 \%$ & 65 & $20,10 \%$ \\
\hline Telecommunication Services & 579 & 39 & $6,70 \%$ & 540 & $93,30 \%$ & 262 & $48,50 \%$ & 224 & $41,50 \%$ & 54 & $10,00 \%$ \\
\hline Utilities & 1055 & 4 & $0,40 \%$ & 1051 & $99,60 \%$ & 459 & $43,70 \%$ & 446 & $42,40 \%$ & 146 & $13,90 \%$ \\
\hline Total & 11322 & 132 & $1,20 \%$ & 11190 & $98,80 \%$ & 4555 & $40,70 \%$ & 4726 & $42,20 \%$ & 1909 & $17,10 \%$ \\
\hline
\end{tabular}


Table 7. Average recommendation on a monthly basis and market performance

\begin{tabular}{|c|c|c|c|c|c|c|c|}
\hline Year & Rating & $B U Y$ & NEUTRAL & SELL & Average Rating & Index data & FTSEMIB \\
\hline 2012 & 29 & 12 & 14 & 3 & 0,310344828 & 01/12/2011 & 15244,62 \\
\hline 2012 & 92 & 33 & 42 & 17 & 0,173913043 & 02/01/2012 & 15089,74 \\
\hline 2012 & 422 & 146 & 173 & 103 & 0,101895735 & $01 / 02 / 2012$ & 16264,55 \\
\hline 2012 & 56 & 26 & 23 & 7 & 0,339285714 & 01/03/2012 & 16830,6 \\
\hline 2012 & 205 & 76 & 98 & 31 & 0,219512195 & 01/04/2012 & 15980,07 \\
\hline 2012 & 217 & 97 & 80 & 40 & 0,262672811 & $01 / 05 / 2012$ & 14592,34 \\
\hline 2012 & 63 & 28 & 24 & 11 & 0,26984127 & 01/06/2012 & 12739,98 \\
\hline 2012 & 168 & 65 & 75 & 28 & 0,220238095 & 01/07/2012 & 14274,37 \\
\hline 2012 & 265 & 114 & 87 & 64 & 0,188679245 & 01/08/2012 & 13928,59 \\
\hline 2012 & 44 & 18 & 15 & 11 & 0,159090909 & 01/09/2012 & 15100,48 \\
\hline 2012 & 198 & 75 & 80 & 43 & 0,161616162 & 01/10/2012 & 15523,1 \\
\hline 2012 & 205 & 98 & 71 & 36 & 0,302439024 & 01/11/2012 & 15806,73 \\
\hline 2013 & 69 & 21 & 29 & 19 & 0,028985507 & 01/12/2012 & 15808,24 \\
\hline 2013 & 99 & 34 & 51 & 14 & 0,202020202 & 01/01/2013 & 16273,38 \\
\hline 2013 & 355 & 125 & 151 & 79 & 0,129577465 & 01/02/2013 & 17318,94 \\
\hline 2013 & 41 & 14 & 22 & 5 & 0,219512195 & $01 / 03 / 2013$ & 15675,37 \\
\hline 2013 & 183 & 45 & 98 & 40 & 0,027322404 & $01 / 04 / 2013$ & 15338,72 \\
\hline 2013 & 248 & 88 & 105 & 55 & 0,133064516 & 01/05/2013 & 16767,66 \\
\hline 2013 & 69 & 23 & 32 & 14 & 0,130434783 & 01/06/2013 & 17214,08 \\
\hline 2013 & 149 & 41 & 71 & 37 & 0,026845638 & $01 / 07 / 2013$ & 15459,57 \\
\hline 2013 & 256 & 97 & 103 & 56 & 0,16015625 & $01 / 08 / 2013$ & 16818,97 \\
\hline 2013 & 66 & 21 & 33 & 12 & 0,136363636 & $01 / 09 / 2013$ & 16682,21 \\
\hline 2013 & 225 & 53 & 119 & 53 & 0 & 01/10/2013 & 17977,06 \\
\hline 2013 & 217 & 100 & 74 & 43 & 0,262672811 & $01 / 11 / 2013$ & 19164,26 \\
\hline 2014 & 50 & 13 & 26 & 11 & 0,04 & $01 / 12 / 2013$ & 19021,48 \\
\hline 2014 & 105 & 35 & 52 & 18 & 0,161904762 & 01/01/2014 & 18967,71 \\
\hline 2014 & 410 & 157 & 159 & 94 & 0,153658537 & $01 / 02 / 2014$ & 19418,34 \\
\hline 2014 & 69 & 18 & 40 & 11 & 0,101449275 & $01 / 03 / 2014$ & 20442,41 \\
\hline 2014 & 224 & 78 & 97 & 49 & 0,129464286 & $01 / 04 / 2014$ & 21915,41 \\
\hline 2014 & 256 & 104 & 102 & 50 & 0,2109375 & $01 / 05 / 2014$ & 21783,38 \\
\hline 2014 & 59 & 14 & 31 & 14 & 0 & $01 / 06 / 2014$ & 21629,71 \\
\hline 2014 & 183 & 65 & 85 & 33 & 0,174863388 & 01/07/2014 & 21563,43 \\
\hline 2014 & 305 & 152 & 116 & 37 & 0,37704918 & 01/08/2014 & 20362,41 \\
\hline 2014 & 51 & 18 & 24 & 9 & 0,176470588 & 01/09/2014 & 20345,85 \\
\hline 2014 & 215 & 80 & 103 & 32 & 0,223255814 & 01/10/2014 & 20706,31 \\
\hline 2014 & 318 & 160 & 110 & 48 & 0,352201258 & $01 / 11 / 2014$ & 19783,99 \\
\hline 2015 & 33 & 7 & 19 & 7 & 0 & $01 / 12 / 2014$ & 19686,45 \\
\hline 2015 & 141 & 54 & 66 & 21 & 0,234042553 & 01/01/2015 & 19011,96 \\
\hline 2015 & 448 & 200 & 178 & 70 & 0,290178571 & $01 / 02 / 2015$ & 20503,38 \\
\hline 2015 & 50 & 13 & 31 & 6 & 0,14 & 01/03/2015 & 22337,79 \\
\hline 2015 & 263 & 94 & 132 & 37 & 0,216730038 & $01 / 04 / 2015$ & 23358,99 \\
\hline 2015 & 307 & 138 & 127 & 42 & 0,312703583 & $01 / 05 / 2015$ & 23045,52 \\
\hline 2015 & 115 & 38 & 57 & 20 & 0,156521739 & $01 / 06 / 2015$ & 23435,67 \\
\hline 2015 & 154 & 57 & 78 & 19 & 0,246753247 & $01 / 07 / 2015$ & 22943,64 \\
\hline 2015 & 323 & 145 & 126 & 52 & 0,287925697 & $01 / 08 / 2015$ & 23538,03 \\
\hline 2015 & 69 & 18 & 35 & 16 & 0,028985507 & $01 / 09 / 2015$ & 21451,37 \\
\hline 2015 & 228 & 70 & 117 & 41 & 0,127192982 & 01/10/2015 & 21142,86 \\
\hline 2015 & 297 & 145 & 111 & 41 & 0,35016835 & $01 / 11 / 2015$ & 22442,51 \\
\hline 2016 & 52 & 19 & 25 & 8 & 0,211538462 & $01 / 12 / 2015$ & 22581,33 \\
\hline 2016 & 144 & 49 & 61 & 34 & 0,104166667 & $01 / 01 / 2016$ & 21418,37 \\
\hline 2016 & 456 & 230 & 182 & 44 & 0,407894737 & $01 / 02 / 2016$ & 18485,95 \\
\hline 2016 & 55 & 19 & 20 & 16 & 0,054545455 & $01 / 03 / 2016$ & 18011,91 \\
\hline 2016 & 210 & 99 & 86 & 25 & 0,352380952 & $01 / 04 / 2016$ & 17776,84 \\
\hline 2016 & 369 & 181 & 152 & 36 & 0,39295393 & $01 / 05 / 2016$ & 18600,56 \\
\hline 2016 & 117 & 46 & 49 & 22 & 0,205128205 & $01 / 06 / 2016$ & 17810,85 \\
\hline 2016 & 166 & 78 & 66 & 22 & 0,337349398 & 01/07/2016 & 16295,78 \\
\hline 2016 & 345 & 192 & 125 & 28 & 0,475362319 & $01 / 08 / 2016$ & 16554,83 \\
\hline 2016 & 49 & 17 & 25 & 7 & 0,204081633 & 01/09/2016 & 16923,28 \\
\hline 2016 & 267 & 127 & 116 & 24 & 0,38576779 & 01/10/2016 & 16401 \\
\hline 2016 & 346 & 175 & 127 & 44 & 0,378612717 & $01 / 11 / 2016$ & 16898,28 \\
\hline Total & 11190 & 4555 & 4726 & 1909 & & & \\
\hline
\end{tabular}


Table 9. Target Price reliability

\begin{tabular}{|c|c|c|c|c|c|c|c|}
\hline \multirow{2}{*}{ Name } & \multicolumn{2}{|c|}{ Target Price } & \multicolumn{2}{|c|}{ Reached TP } & \multicolumn{2}{|c|}{ +/- 5\% Reached TP } & \multirow{2}{*}{$\begin{array}{c}\text { Average } \\
T P / P \\
\end{array}$} \\
\hline & $N^{\circ}$ & $\%$ & $N^{\circ}$ & $\%$ & $N^{\circ}$ & $\%$ & \\
\hline ENI SPA & 553 & $88,20 \%$ & 276 & $49,90 \%$ & 386 & $69,80 \%$ & $10,30 \%$ \\
\hline ENEL SPA & 477 & $90,30 \%$ & 250 & $52,40 \%$ & 302 & $63,30 \%$ & $10,90 \%$ \\
\hline INTESA SANPAOLO & 535 & $91,60 \%$ & 316 & $59,10 \%$ & 372 & $69,50 \%$ & $12,90 \%$ \\
\hline UNICREDIT SPA & 567 & $89,90 \%$ & 0 & $0,00 \%$ & 0 & $0,00 \%$ & $16,00 \%$ \\
\hline ASSICURAZIONI GENERALI & 496 & $88,30 \%$ & 285 & $57,50 \%$ & 369 & $74,40 \%$ & $7,80 \%$ \\
\hline ATLANTIA SPA & 317 & $90,30 \%$ & 190 & $59,90 \%$ & 219 & $69,10 \%$ & $14,50 \%$ \\
\hline FIAT CHRYSLER AUTOMOBILES NV & 194 & $87,40 \%$ & 112 & $57,70 \%$ & 128 & $66,00 \%$ & $16,30 \%$ \\
\hline SNAM SPA & 372 & $95,10 \%$ & 164 & $44,10 \%$ & 232 & $62,40 \%$ & $6,10 \%$ \\
\hline TELECOM ITALIA SPA & 485 & $83,80 \%$ & 254 & $52,40 \%$ & 304 & $62,70 \%$ & $18,70 \%$ \\
\hline FERRARI NV & 57 & $91,90 \%$ & 34 & $59,60 \%$ & 39 & $68,40 \%$ & $8,30 \%$ \\
\hline CNH INDUSTRIAL NV & 210 & $91,70 \%$ & 124 & $59,00 \%$ & 150 & $71,40 \%$ & $8,30 \%$ \\
\hline STMICROELECTRONICS NV & 324 & $93,60 \%$ & 237 & $73,10 \%$ & 267 & $82,40 \%$ & $2,40 \%$ \\
\hline LUXOTTICA GROUP SPA & 339 & $89,90 \%$ & 233 & $68,70 \%$ & 271 & $79,90 \%$ & $3,10 \%$ \\
\hline TERNA SPA & 318 & $95,80 \%$ & 267 & $84,00 \%$ & 300 & $94,30 \%$ & $3,30 \%$ \\
\hline TENARIS SA & 228 & $84,80 \%$ & 156 & $68,40 \%$ & 179 & $78,50 \%$ & $2,70 \%$ \\
\hline EXOR NV & 74 & $94,90 \%$ & 51 & $68,90 \%$ & 61 & $82,40 \%$ & $8,60 \%$ \\
\hline LEONARDO SPA & 252 & $91,60 \%$ & 167 & $66,30 \%$ & 190 & $75,40 \%$ & $11,50 \%$ \\
\hline PRYSMIAN SPA & 301 & $95,00 \%$ & 231 & $76,70 \%$ & 266 & $88,40 \%$ & $13,90 \%$ \\
\hline MEDIOBANCA SPA & 197 & $91,60 \%$ & 153 & $77,70 \%$ & 163 & $82,70 \%$ & $18,00 \%$ \\
\hline BANCO BPM SPA & 288 & $92,30 \%$ & 178 & $61,80 \%$ & 180 & $62,50 \%$ & $17,10 \%$ \\
\hline MONCLER SPA & 180 & $95,70 \%$ & 72 & $40,00 \%$ & 108 & $60,00 \%$ & $19,30 \%$ \\
\hline RECORDATI SPA & 123 & $94,60 \%$ & 94 & $76,40 \%$ & 106 & $86,20 \%$ & $7,30 \%$ \\
\hline UBI BANCA SPA & 310 & $93,90 \%$ & 199 & $64,20 \%$ & 229 & $73,90 \%$ & $14,60 \%$ \\
\hline DAVIDE CAMPARI-MILANO SPA & 304 & $93,00 \%$ & 0 & $0,00 \%$ & 0 & $0,00 \%$ & $-0,10 \%$ \\
\hline POSTE ITALIANE SPA & 47 & $97,90 \%$ & 3 & $6,40 \%$ & 11 & $23,40 \%$ & $19,80 \%$ \\
\hline FINECOBANK SPA & 62 & $95,40 \%$ & 34 & $54,80 \%$ & 46 & $74,20 \%$ & $8,70 \%$ \\
\hline BPER BANCA & 164 & $91,10 \%$ & 106 & $64,60 \%$ & 120 & $73,20 \%$ & $23,60 \%$ \\
\hline SAIPEM SPA & 454 & $91,90 \%$ & 160 & $35,20 \%$ & 166 & $36,60 \%$ & $8,50 \%$ \\
\hline UNIPOLSAI ASSICURAZIONI SPA & 118 & $81,90 \%$ & 71 & $60,20 \%$ & 87 & $73,70 \%$ & $8,10 \%$ \\
\hline A2A SPA & 160 & $89,40 \%$ & 105 & $65,60 \%$ & 121 & $75,60 \%$ & $14,30 \%$ \\
\hline ITALGAS SPA & 16 & $100,00 \%$ & 2 & $12,50 \%$ & 4 & $25,00 \%$ & $20,40 \%$ \\
\hline AZIMUT HOLDING SPA & 136 & $89,50 \%$ & 94 & $69,10 \%$ & 100 & $73,50 \%$ & $16,90 \%$ \\
\hline UNIPOL GRUPPO FINANZIARIO SP & 125 & $83,90 \%$ & 62 & $49,60 \%$ & 70 & $56,00 \%$ & $24,90 \%$ \\
\hline BREMBO SPA & 166 & $92,20 \%$ & 148 & $89,20 \%$ & 156 & $94,00 \%$ & $7,70 \%$ \\
\hline SALVATORE FERRAGAMO SPA & 344 & $96,40 \%$ & 235 & $68,30 \%$ & 278 & $80,80 \%$ & $7,50 \%$ \\
\hline BANCA MEDIOLANUM SPA & 22 & $78,60 \%$ & 11 & $50,00 \%$ & 18 & $81,80 \%$ & $14,60 \%$ \\
\hline BUZZI UNICEM SPA & 292 & $90,40 \%$ & 240 & $82,20 \%$ & 263 & $90,10 \%$ & $11,70 \%$ \\
\hline BANCA GENERALI SPA & 132 & $86,30 \%$ & 96 & $72,70 \%$ & 114 & $86,40 \%$ & $10,70 \%$ \\
\hline YOOX NET-A-PORTER GROUP & 154 & $89,00 \%$ & 90 & $58,40 \%$ & 99 & $64,30 \%$ & $19,70 \%$ \\
\hline MEDIASET SPA & 397 & $94,70 \%$ & 270 & $68,00 \%$ & 305 & $76,80 \%$ & $2,90 \%$ \\
\hline Total & 10290 & $90,90 \%$ & 5770 & $56,10 \%$ & 6779 & $65,90 \%$ & $10,90 \%$ \\
\hline
\end{tabular}


Table 12. Target price/Price ratio

\begin{tabular}{|c|c|c|c|c|c|c|c|}
\hline \multirow{2}{*}{ Name } & \multirow{2}{*}{$\begin{array}{c}\text { Average } \\
\text { TP/P }\end{array}$} & \multicolumn{2}{|c|}{$B U Y$} & \multicolumn{2}{|c|}{ NEUTRAL } & \multicolumn{2}{|c|}{ SELL } \\
\hline & & $N^{\circ} T P$ & TP/P Medio & $N^{\circ} T P$ & TP/P Medio & $N^{\circ} T P$ & TP/P Medio \\
\hline ENI SPA & $10,30 \%$ & 237 & $19,80 \%$ & 225 & $5,80 \%$ & 91 & $-3,20 \%$ \\
\hline ENEL SPA & $10,90 \%$ & 238 & $18,60 \%$ & 184 & $6,20 \%$ & 55 & $-6,80 \%$ \\
\hline INTESA SANPAOLO & $12,90 \%$ & 248 & $24,70 \%$ & 194 & $11,40 \%$ & 93 & $-15,40 \%$ \\
\hline UNICREDIT SPA & $16,00 \%$ & 216 & $34,80 \%$ & 225 & $13,00 \%$ & 126 & $-10,80 \%$ \\
\hline ASSICURAZIONI GENERALI & $7,80 \%$ & 147 & $23,40 \%$ & 206 & $7,30 \%$ & 143 & $-7,60 \%$ \\
\hline ATLANTIA SPA & $14,50 \%$ & 227 & $17,40 \%$ & 84 & $7,60 \%$ & 6 & $-0,60 \%$ \\
\hline FIAT CHRYSLER AUTOMOBILES NV & $16,30 \%$ & 93 & $33,90 \%$ & 59 & $15,00 \%$ & 41 & $-23,30 \%$ \\
\hline SNAM SPA & $6,10 \%$ & 178 & $11,60 \%$ & 171 & $1,60 \%$ & 23 & $-2,30 \%$ \\
\hline TELECOM ITALIA SPA & $18,70 \%$ & 241 & $31,40 \%$ & 194 & $10,70 \%$ & 50 & $-11,20 \%$ \\
\hline FERRARI NV & $8,30 \%$ & 33 & $20,00 \%$ & 8 & $9,80 \%$ & 16 & $-15,00 \%$ \\
\hline CNH INDUSTRIAL NV & $8,30 \%$ & 57 & $27,70 \%$ & 111 & $8,10 \%$ & 42 & $-16,60 \%$ \\
\hline STMICROELECTRONICS NV & $2,40 \%$ & 61 & $24,20 \%$ & 176 & $2,90 \%$ & 87 & $-13,90 \%$ \\
\hline LUXOTTICA GROUP SPA & $3,10 \%$ & 140 & $12,50 \%$ & 144 & $-0,30 \%$ & 55 & $-11,80 \%$ \\
\hline TERNA SPA & $3,30 \%$ & 101 & $11,40 \%$ & 157 & $1,30 \%$ & 60 & $-5,30 \%$ \\
\hline TENARIS SA & $2,70 \%$ & 56 & $21,50 \%$ & 93 & $3,20 \%$ & 79 & $-11,20 \%$ \\
\hline EXOR NV & $8,60 \%$ & 22 & $22,10 \%$ & 51 & $3,20 \%$ & 1 & $-13,10 \%$ \\
\hline LEONARDO SPA & $11,50 \%$ & 109 & $30,30 \%$ & 94 & $5,70 \%$ & 49 & $-19,10 \%$ \\
\hline PRYSMIAN SPA & $13,90 \%$ & 202 & $17,20 \%$ & 94 & $7,60 \%$ & 5 & $-0,40 \%$ \\
\hline MEDIOBANCA SPA & $18,00 \%$ & 102 & $27,10 \%$ & 86 & $9,40 \%$ & 9 & $-2,50 \%$ \\
\hline BANCO BPM SPA & $17,10 \%$ & 85 & $37,20 \%$ & 152 & $14,70 \%$ & 51 & $-9,20 \%$ \\
\hline MONCLER SPA & $19,30 \%$ & 124 & $24,10 \%$ & 48 & $11,70 \%$ & 8 & $-10,20 \%$ \\
\hline RECORDATI SPA & $7,30 \%$ & 49 & $16,60 \%$ & 69 & $0,80 \%$ & 5 & $7,20 \%$ \\
\hline UBI BANCA SPA & $14,60 \%$ & 96 & $28,80 \%$ & 163 & $13,70 \%$ & 51 & $-9,50 \%$ \\
\hline DAVIDE CAMPARI-MILANO SPA & $-0,10 \%$ & 73 & $13,50 \%$ & 156 & $-1,20 \%$ & 75 & $-11,30 \%$ \\
\hline POSTE ITALIANE SPA & $19,80 \%$ & 29 & $25,50 \%$ & 18 & $10,60 \%$ & 0 & \\
\hline FINECOBANK SPA & $8,70 \%$ & 34 & $16,40 \%$ & 24 & $0,20 \%$ & 4 & $-5,90 \%$ \\
\hline BPER BANCA & $23,60 \%$ & 83 & $34,70 \%$ & 72 & $14,70 \%$ & 9 & $-6,90 \%$ \\
\hline SAIPEM SPA & $8,50 \%$ & 118 & $26,10 \%$ & 223 & $9,20 \%$ & 113 & $-11,10 \%$ \\
\hline UNIPOLSAI ASSICURAZIONI SPA & $8,10 \%$ & 50 & $18,20 \%$ & 51 & $4,00 \%$ & 17 & $-9,60 \%$ \\
\hline A2A SPA & $14,30 \%$ & 84 & $20,70 \%$ & 59 & $11,10 \%$ & 17 & $-5,90 \%$ \\
\hline ITALGAS SPA & $20,40 \%$ & 12 & $21,80 \%$ & 4 & $16,20 \%$ & 0 & \\
\hline AZIMUT HOLDING SPA & $16,90 \%$ & 75 & $24,40 \%$ & 48 & $12,80 \%$ & 13 & $-11,70 \%$ \\
\hline UNIPOL GRUPPO FINANZIARIO SP & $24,90 \%$ & 86 & $30,60 \%$ & 22 & $26,30 \%$ & 17 & $-6,10 \%$ \\
\hline BREMBO SPA & $7,70 \%$ & 91 & $14,10 \%$ & 68 & $1,30 \%$ & 7 & $-12,60 \%$ \\
\hline SALVATORE FERRAGAMO SPA & $7,50 \%$ & 93 & $16,60 \%$ & 212 & $6,40 \%$ & 39 & $-8,00 \%$ \\
\hline BANCA MEDIOLANUM SPA & $14,60 \%$ & 14 & $12,70 \%$ & 8 & $17,80 \%$ & 0 & \\
\hline BUZZI UNICEM SPA & $11,70 \%$ & 138 & $23,30 \%$ & 106 & $5,60 \%$ & 48 & $-8,50 \%$ \\
\hline BANCA GENERALI SPA & $10,70 \%$ & 72 & $17,60 \%$ & 58 & $3,20 \%$ & 2 & $-16,20 \%$ \\
\hline YOOX NET-A-PORTER GROUP & $19,70 \%$ & 90 & $27,10 \%$ & 48 & $18,80 \%$ & 16 & $-18,60 \%$ \\
\hline MEDIASET SPA & $2,90 \%$ & 109 & $28,70 \%$ & 165 & $2,60 \%$ & 123 & $-19,60 \%$ \\
\hline Total & $10,90 \%$ & 4313 & $23,00 \%$ & 4330 & $7,20 \%$ & 1646 & $-11,10 \%$ \\
\hline
\end{tabular}

Table 14. Target price reliability and TP/P ratio on sector basis

\begin{tabular}{|c|c|c|c|c|c|c|c|}
\hline \multirow{2}{*}{ Name } & \multicolumn{2}{|c|}{ Target Price } & \multicolumn{2}{|c|}{ Reached TP } & \multicolumn{2}{|c|}{ +/- 5\% Reached TP } & \multirow{2}{*}{$\begin{array}{c}\text { Average } \\
T P / P\end{array}$} \\
\hline & $N^{\circ}$ & $\%$ & $N^{\circ}$ & $\%$ & $N^{\circ}$ & $\%$ & \\
\hline Consumer Discretionary & 1831 & $92,60 \%$ & 1194 & $65,20 \%$ & 1384 & $75,60 \%$ & $8,80 \%$ \\
\hline Consumer Staples & 304 & $93,00 \%$ & 0 & $0,00 \%$ & 0 & $0,00 \%$ & $-0,10 \%$ \\
\hline Energy & 1607 & $90,20 \%$ & 756 & $47,00 \%$ & 963 & $59,90 \%$ & $7,80 \%$ \\
\hline Financials & 3273 & $90,10 \%$ & 1659 & $50,70 \%$ & 1940 & $59,30 \%$ & $14,30 \%$ \\
\hline Health Care & 123 & $94,60 \%$ & 94 & $76,40 \%$ & 106 & $86,20 \%$ & $7,30 \%$ \\
\hline Industrials & 1080 & $92,20 \%$ & 712 & $65,90 \%$ & 825 & $76,40 \%$ & $12,40 \%$ \\
\hline Information Technology & 324 & $93,60 \%$ & 237 & $73,10 \%$ & 267 & $82,40 \%$ & $2,40 \%$ \\
\hline Materials & 292 & $90,40 \%$ & 240 & $82,20 \%$ & 263 & $90,10 \%$ & $11,70 \%$ \\
\hline Telecommunication Services & 485 & $83,80 \%$ & 254 & $52,40 \%$ & 304 & $62,70 \%$ & $18,70 \%$ \\
\hline Utilities & 971 & $92,00 \%$ & 624 & $64,30 \%$ & 727 & $74,90 \%$ & $9,10 \%$ \\
\hline Total & 10290 & $90,90 \%$ & 5770 & $56,10 \%$ & 6779 & $65,90 \%$ & $10,90 \%$ \\
\hline
\end{tabular}


Table 15. Issuing Brokers (F=Foreign; I=Italian): details on the reports, target price reliability

\begin{tabular}{|c|c|c|c|c|c|c|c|c|c|}
\hline \multirow{2}{*}{ Broker } & \multirow{2}{*}{ Nationality } & \multirow{2}{*}{\begin{tabular}{|c|} 
Total \\
Reports
\end{tabular}} & \multirow{2}{*}{$\begin{array}{c}\text { Total } \\
\text { Recomandations }\end{array}$} & \multirow{2}{*}{ Not Rated } & \multirow{2}{*}{ Target Price } & \multicolumn{2}{|c|}{ Reached TP } & \multicolumn{2}{|c|}{ +/-5\% Reached TP } \\
\hline & & & & & & $N^{\circ}$ & $\%$ & $N^{\circ}$ & $\%$ \\
\hline ABN Amro Bank N.V. & $\mathrm{F}$ & 7 & 7 & 0 & 7 & 2 & $28,60 \%$ & 2 & $28,60 \%$ \\
\hline Ahorro Corporacion Financiera SA & $\mathrm{F}$ & 2 & 2 & 0 & 2 & 1 & $50,00 \%$ & 1 & $50,00 \%$ \\
\hline Allaria Ledesma y Cia & $\mathrm{F}$ & 6 & 6 & 0 & 5 & 2 & $40,00 \%$ & 2 & $40,00 \%$ \\
\hline AlphaValue & $\mathrm{F}$ & 362 & 362 & 0 & 344 & 182 & $52,90 \%$ & 227 & $66,00 \%$ \\
\hline Aurel BGC & $\mathrm{F}$ & 19 & 19 & 0 & 19 & 11 & $57,90 \%$ & 14 & $73,70 \%$ \\
\hline Baader-Helvea & $\mathrm{F}$ & 18 & 18 & 0 & 18 & 16 & $88,90 \%$ & 16 & $88,90 \%$ \\
\hline Banca Akros(ESN) & I & 633 & 612 & 21 & 611 & 362 & $59,20 \%$ & 398 & $65,10 \%$ \\
\hline Banca Aletti & I & 69 & 69 & 0 & 69 & 48 & $69,60 \%$ & 53 & $76,80 \%$ \\
\hline Banca IMI & I & 573 & 557 & 16 & 536 & 292 & $54,50 \%$ & 361 & $67,40 \%$ \\
\hline Banca Profilo & I & 4 & 4 & 0 & 4 & 4 & $100,00 \%$ & 4 & $100,00 \%$ \\
\hline Banco Sabadell & $\mathrm{F}$ & 43 & 43 & 0 & 37 & 12 & $32,40 \%$ & 18 & $48,60 \%$ \\
\hline Bank am Bellevue & $\mathrm{F}$ & 10 & 10 & 0 & 9 & 3 & $33,30 \%$ & 3 & $33,30 \%$ \\
\hline Bankhaus Lampe & $\mathrm{F}$ & 13 & 13 & 0 & 13 & 5 & $38,50 \%$ & 9 & $69,20 \%$ \\
\hline Barclays & $\mathrm{F}$ & 339 & 339 & 0 & 339 & 178 & $52,50 \%$ & 212 & $62,50 \%$ \\
\hline BBVA & F & 9 & 9 & 0 & 8 & 0 & $0,00 \%$ & 0 & $0,00 \%$ \\
\hline Berenberg & $\mathrm{F}$ & 216 & 216 & 0 & 215 & 111 & $51,60 \%$ & 128 & $59,50 \%$ \\
\hline Bernstein & $\mathrm{F}$ & 160 & 160 & 0 & 160 & 51 & $31,90 \%$ & 67 & $41,90 \%$ \\
\hline BMO Capital Markets & F & 10 & 10 & 0 & 10 & 10 & $100,00 \%$ & 10 & $100,00 \%$ \\
\hline Bryan Garnier \& Cie & $\mathrm{F}$ & 62 & 62 & 0 & 62 & 32 & $51,60 \%$ & 42 & $67,70 \%$ \\
\hline CA Cheuvreux & $\mathrm{F}$ & 96 & 96 & 0 & 96 & 71 & $74,00 \%$ & 78 & $81,30 \%$ \\
\hline Canaccord Genuity & $\mathrm{F}$ & 38 & 38 & 0 & 37 & 25 & $67,60 \%$ & 25 & $67,60 \%$ \\
\hline Cantor Fitzgerald & $\mathrm{F}$ & 7 & 7 & 0 & 7 & 5 & $71,40 \%$ & 7 & $100,00 \%$ \\
\hline Cenkos Securities Ltd & $\mathrm{F}$ & 1 & 1 & 0 & 0 & 0 & & 0 & \\
\hline Centrobanca & I & 49 & 49 & 0 & 49 & 35 & $71,40 \%$ & 39 & $79,60 \%$ \\
\hline Churchill Research & F & 1 & 0 & 1 & 1 & 0 & $0,00 \%$ & 0 & $0,00 \%$ \\
\hline CM Research & $\mathrm{F}$ & 3 & 3 & 0 & 3 & 1 & $33,30 \%$ & 2 & $66,70 \%$ \\
\hline Commerzbank & $\mathrm{F}$ & 9 & 9 & 0 & 9 & 4 & $44,40 \%$ & 4 & $44,40 \%$ \\
\hline Credit Suisse & $\mathrm{F}$ & 285 & 282 & 3 & 282 & 151 & $53,50 \%$ & 183 & $64,90 \%$ \\
\hline Davy & F & 13 & 13 & 0 & 0 & 0 & & 0 & \\
\hline Day by Day & $\mathrm{F}$ & 142 & 142 & 0 & 63 & 36 & $57,10 \%$ & 44 & $69,80 \%$ \\
\hline DNB Markets & $\mathrm{F}$ & 13 & 13 & 0 & 13 & 6 & $46,20 \%$ & 6 & $46,20 \%$ \\
\hline DZ Bank AG & F & 21 & 21 & 0 & 21 & 5 & $23,80 \%$ & 6 & $28,60 \%$ \\
\hline Equita SIM SpA & I & 623 & 623 & 0 & 623 & 397 & $63,70 \%$ & 458 & $73,50 \%$ \\
\hline Erste Group & $\mathrm{F}$ & 5 & 5 & 0 & 0 & 0 & & 0 & \\
\hline EVA Dimensions & F & 395 & 395 & 0 & 0 & 0 & & 0 & \\
\hline Evercore ISI & $\mathrm{F}$ & 40 & 40 & 0 & 40 & 18 & $45,00 \%$ & 21 & $52,50 \%$ \\
\hline Exane BNP Paribas & $\mathrm{F}$ & 499 & 499 & 0 & 499 & 310 & $62,10 \%$ & 352 & $70,50 \%$ \\
\hline Fidentiis Equities & F & 170 & 170 & 0 & 162 & 71 & $43,80 \%$ & 93 & $57,40 \%$ \\
\hline Freedom Finance & $\mathrm{F}$ & 2 & 2 & 0 & 2 & 1 & $50,00 \%$ & 1 & $50,00 \%$ \\
\hline Gabelli \& Co & F & 1 & 1 & 0 & 0 & 0 & & 0 & \\
\hline Goldman Sachs & F & 495 & 481 & 14 & 481 & 240 & $49,90 \%$ & 288 & $59,90 \%$ \\
\hline Grupo Santander & $\mathrm{F}$ & 107 & 107 & 0 & 106 & 32 & $30,20 \%$ & 46 & $43,40 \%$ \\
\hline Haitong & $\mathrm{F}$ & 49 & 49 & 0 & 48 & 30 & $62,50 \%$ & 36 & $75,00 \%$ \\
\hline Hamburger Sparkasse & $\mathrm{F}$ & 41 & 41 & 0 & 0 & 0 & & 0 & \\
\hline Hammer Partners SA & $\mathrm{F}$ & 143 & 143 & 0 & 136 & 67 & $49,30 \%$ & 76 & $55,90 \%$ \\
\hline HSBC & $\mathrm{F}$ & 260 & 260 & 0 & 260 & 172 & $66,20 \%$ & 192 & $73,80 \%$ \\
\hline ICBPI & I & 390 & 339 & 51 & 304 & 174 & $57,20 \%$ & 196 & $64,50 \%$ \\
\hline Independent Research GmbH & $\mathrm{F}$ & 120 & 120 & 0 & 120 & 67 & $55,80 \%$ & 84 & $70,00 \%$ \\
\hline ING Bank & $\mathrm{F}$ & 20 & 20 & 0 & 20 & 13 & $65,00 \%$ & 14 & $70,00 \%$ \\
\hline Insight Investment Research LLP & $\mathrm{F}$ & 13 & 13 & 0 & 13 & 3 & $23,10 \%$ & 5 & $38,50 \%$ \\
\hline Intermonte Securities SpA & I & 1 & 1 & 0 & 1 & 1 & $100,00 \%$ & 1 & $100,00 \%$ \\
\hline Investec & $\mathrm{F}$ & 28 & 28 & 0 & 28 & 16 & $57,10 \%$ & 17 & $60,70 \%$ \\
\hline J.P. Morgan & $\mathrm{F}$ & 349 & 349 & 0 & 349 & 194 & $55,60 \%$ & 232 & $66,50 \%$ \\
\hline Jefferies & $\mathrm{F}$ & 125 & 125 & 0 & 125 & 83 & $66,40 \%$ & 95 & $76,00 \%$ \\
\hline Keefe, Bruyette \& Woods & $\mathrm{F}$ & 142 & 142 & 0 & 141 & 75 & $53,20 \%$ & 85 & $60,30 \%$ \\
\hline Kempen \& Co & $\mathrm{F}$ & 4 & 4 & 0 & 4 & 2 & $50,00 \%$ & 3 & $75,00 \%$ \\
\hline Kepler Cheuvreux & $\mathrm{F}$ & 564 & 562 & 2 & 562 & 336 & $59,80 \%$ & 397 & $70,60 \%$ \\
\hline KeyBanc Capital Markets & F & 1 & 1 & 0 & 1 & 0 & $0,00 \%$ & 0 & $0,00 \%$ \\
\hline Landesbank Baden-Wuerttemberg & $\mathrm{F}$ & 109 & 109 & 0 & 109 & 53 & $48,60 \%$ & 74 & $67,90 \%$ \\
\hline Liberum & $\mathrm{F}$ & 65 & 65 & 0 & 58 & 33 & $56,90 \%$ & 36 & $62,10 \%$ \\
\hline
\end{tabular}




\begin{tabular}{|c|c|c|c|c|c|c|c|c|c|}
\hline Macquarie & $\mathrm{F}$ & 156 & 156 & 0 & 156 & 83 & $53,20 \%$ & 99 & $63,50 \%$ \\
\hline MainFirst Bank AG & $\mathrm{F}$ & 213 & 213 & 0 & 213 & 120 & $56,30 \%$ & 150 & $70,40 \%$ \\
\hline Makor Capital & $\mathrm{F}$ & 11 & 11 & 0 & 1 & 1 & $100,00 \%$ & 1 & $100,00 \%$ \\
\hline Mediobanca SpA & I & 619 & 601 & 18 & 598 & 320 & $53,50 \%$ & 377 & $63,00 \%$ \\
\hline Mirabaud Securities & $\mathrm{F}$ & 24 & 24 & 0 & 22 & 18 & $81,80 \%$ & 21 & $95,50 \%$ \\
\hline Morgan Stanley & $\mathrm{F}$ & 332 & 327 & 5 & 327 & 202 & $61,80 \%$ & 226 & $69,10 \%$ \\
\hline Morningstar, Inc & $\mathrm{F}$ & 130 & 130 & 0 & 0 & 0 & & 0 & \\
\hline $\mathrm{N}+1$ Singer Ltd & $\mathrm{F}$ & 9 & 9 & 0 & 9 & 8 & $88,90 \%$ & 9 & $100,00 \%$ \\
\hline National Bank AG & $\mathrm{F}$ & 22 & 22 & 0 & 19 & 12 & $63,20 \%$ & 14 & $73,70 \%$ \\
\hline Natixis & $\mathrm{F}$ & 271 & 271 & 0 & 271 & 161 & $59,40 \%$ & 187 & $69,00 \%$ \\
\hline New Street Research & $\mathrm{F}$ & 16 & 16 & 0 & 16 & 13 & $81,30 \%$ & 14 & $87,50 \%$ \\
\hline Nomura & $\mathrm{F}$ & 255 & 255 & 0 & 255 & 165 & $64,70 \%$ & 182 & $71,40 \%$ \\
\hline Nord/LB & $\mathrm{F}$ & 8 & 8 & 0 & 3 & 1 & $33,30 \%$ & 1 & $33,30 \%$ \\
\hline Oddo \& Cie & $\mathrm{F}$ & 154 & 154 & 0 & 151 & 86 & $57,00 \%$ & 102 & $67,50 \%$ \\
\hline Piper Jaffray & $\mathrm{F}$ & 13 & 13 & 0 & 13 & 6 & $46,20 \%$ & 9 & $69,20 \%$ \\
\hline Raymond James & $\mathrm{F}$ & 91 & 91 & 0 & 69 & 25 & $36,20 \%$ & 34 & $49,30 \%$ \\
\hline RBC Capital Markets & $\mathrm{F}$ & 158 & 158 & 0 & 158 & 70 & $44,30 \%$ & 88 & $55,70 \%$ \\
\hline Redburn & $\mathrm{F}$ & 70 & 70 & 0 & 0 & 0 & & 0 & \\
\hline S\&P Capital IQ & $\mathrm{F}$ & 105 & 105 & 0 & 105 & 52 & $49,50 \%$ & 60 & $57,10 \%$ \\
\hline Seaport Global Securities & $\mathrm{F}$ & 11 & 11 & 0 & 11 & 10 & $90,90 \%$ & 11 & $100,00 \%$ \\
\hline SEB Equities & $\mathrm{F}$ & 7 & 7 & 0 & 7 & 5 & $71,40 \%$ & 5 & $71,40 \%$ \\
\hline Silvia Quandt Research & $\mathrm{F}$ & 3 & 3 & 0 & 3 & 3 & $100,00 \%$ & 3 & $100,00 \%$ \\
\hline Societe Generale & $\mathrm{F}$ & 322 & 321 & 1 & 321 & 153 & $47,70 \%$ & 186 & $57,90 \%$ \\
\hline Spin-Off Research & $\mathrm{F}$ & 9 & 9 & 0 & 9 & 9 & $100,00 \%$ & 9 & $100,00 \%$ \\
\hline Stifel & $\mathrm{F}$ & 4 & 4 & 0 & 2 & 2 & $100,00 \%$ & 2 & $100,00 \%$ \\
\hline UBS & $\mathrm{F}$ & 284 & 284 & 0 & 284 & 179 & $63,00 \%$ & 206 & $72,50 \%$ \\
\hline Value Investment Principals & $\mathrm{F}$ & 1 & 1 & 0 & 1 & 0 & $0,00 \%$ & 0 & $0,00 \%$ \\
\hline VTB Capital & $\mathrm{F}$ & 7 & 7 & 0 & 7 & 5 & $71,40 \%$ & 7 & $100,00 \%$ \\
\hline WestLB Equity Markets & $\mathrm{F}$ & 5 & 5 & 0 & 1 & 1 & $100,00 \%$ & 1 & $100,00 \%$ \\
\hline WhiteSand Research LLC & $\mathrm{F}$ & 1 & 1 & 0 & 1 & 0 & $0,00 \%$ & 0 & $0,00 \%$ \\
\hline Whitman Howard & $\mathrm{F}$ & 2 & 2 & 0 & 2 & 0 & $0,00 \%$ & 0 & $0,00 \%$ \\
\hline William Blair \& Co & $\mathrm{F}$ & 14 & 14 & 0 & 14 & 11 & $78,60 \%$ & 12 & $85,70 \%$ \\
\hline Williams Financial Group & $\mathrm{F}$ & 1 & 1 & 0 & 0 & 0 & & 0 & \\
\hline Total & & 11322 & 11190 & 132 & 10290 & 5770 & $56,10 \%$ & 6779 & $65,90 \%$ \\
\hline
\end{tabular}

Table 17. Intermediaries and breakdown of the number of reports for recommendation category

\begin{tabular}{|c|c|c|c|c|c|c|c|c|c|c|c|}
\hline \multirow{2}{*}{ Broker } & \multirow{2}{*}{ Nationality } & \multirow{2}{*}{$\begin{array}{c}\text { Total } \\
\text { Reports }\end{array}$} & \multirow{2}{*}{$\begin{array}{c}\text { Total } \\
\text { Recomandations }\end{array}$} & \multirow{2}{*}{$\begin{array}{c}\text { Not } \\
\text { Rated }\end{array}$} & \multicolumn{2}{|c|}{$B U Y$} & \multicolumn{2}{|c|}{ NEUTRAL } & \multicolumn{2}{|c|}{ SELL } & \multirow{2}{*}{$\begin{array}{c}\text { Average } \\
\text { Rating }\end{array}$} \\
\hline & & & & & $N^{\circ}$ & $\%$ & $N^{\circ}$ & $\%$ & $N^{\circ}$ & $\%$ & \\
\hline ABN Amro Bank N.V. & $\mathrm{F}$ & 7 & 7 & 0 & 1 & $14,30 \%$ & 6 & $85,70 \%$ & 0 & $0,00 \%$ & 0,14 \\
\hline Ahorro Corporacion Financiera SA & $\mathrm{F}$ & 2 & 2 & 0 & 1 & $50,00 \%$ & 0 & $0,00 \%$ & 1 & $50,00 \%$ & 0 \\
\hline Allaria Ledesma y Cia & $\mathrm{F}$ & 6 & 6 & 0 & 2 & $33,30 \%$ & 3 & $50,00 \%$ & 1 & $16,70 \%$ & 0,17 \\
\hline AlphaValue & $\mathrm{F}$ & 362 & 362 & 0 & 254 & $70,20 \%$ & 0 & $0,00 \%$ & 108 & $29,80 \%$ & 0,4 \\
\hline Aurel BGC & $\mathrm{F}$ & 19 & 19 & 0 & 5 & $26,30 \%$ & 10 & $52,60 \%$ & 4 & $21,10 \%$ & 0,05 \\
\hline Baader-Helvea & $\mathrm{F}$ & 18 & 18 & 0 & 8 & $44,40 \%$ & 10 & $55,60 \%$ & 0 & $0,00 \%$ & 0,44 \\
\hline Banca Akros(ESN) & I & 633 & 612 & 21 & 345 & $56,40 \%$ & 241 & $39,40 \%$ & 26 & $4,20 \%$ & 0,52 \\
\hline Banca Aletti & I & 69 & 69 & 0 & 35 & $50,70 \%$ & 22 & $31,90 \%$ & 12 & $17,40 \%$ & 0,33 \\
\hline Banca IMI & I & 573 & 557 & 16 & 320 & $57,50 \%$ & 209 & $37,50 \%$ & 28 & $5,00 \%$ & 0,52 \\
\hline Banca Profilo & I & 4 & 4 & 0 & 0 & $0,00 \%$ & 4 & $100,00 \%$ & 0 & $0,00 \%$ & 0 \\
\hline Banco Sabadell & $\mathrm{F}$ & 43 & 43 & 0 & 30 & $69,80 \%$ & 0 & $0,00 \%$ & 13 & $30,20 \%$ & 0,4 \\
\hline Bank am Bellevue & $\mathrm{F}$ & 10 & 10 & 0 & 6 & $60,00 \%$ & 4 & $40,00 \%$ & 0 & $0,00 \%$ & 0,6 \\
\hline Bankhaus Lampe & $\mathrm{F}$ & 13 & 13 & 0 & 6 & $46,20 \%$ & 7 & $53,80 \%$ & 0 & $0,00 \%$ & 0,46 \\
\hline Barclays & $\mathrm{F}$ & 339 & 339 & 0 & 134 & $39,50 \%$ & 139 & $41,00 \%$ & 66 & $19,50 \%$ & 0,2 \\
\hline BBVA & $\mathrm{F}$ & 9 & 9 & 0 & 9 & $100,00 \%$ & 0 & $0,00 \%$ & 0 & $0,00 \%$ & 1 \\
\hline Berenberg & $\mathrm{F}$ & 216 & 216 & 0 & 77 & $35,60 \%$ & 84 & $38,90 \%$ & 55 & $25,50 \%$ & 0,1 \\
\hline Bernstein & $\mathrm{F}$ & 160 & 160 & 0 & 71 & $44,40 \%$ & 42 & $26,30 \%$ & 47 & $29,40 \%$ & 0,15 \\
\hline BMO Capital Markets & $\mathrm{F}$ & 10 & 10 & 0 & 0 & $0,00 \%$ & 9 & $90,00 \%$ & 1 & $10,00 \%$ & $-0,1$ \\
\hline Bryan Garnier \& Cie & $\mathrm{F}$ & 62 & 62 & 0 & 34 & $54,80 \%$ & 26 & $41,90 \%$ & 2 & $3,20 \%$ & 0,52 \\
\hline CA Cheuvreux & $\mathrm{F}$ & 96 & 96 & 0 & 44 & $45,80 \%$ & 0 & $0,00 \%$ & 52 & $54,20 \%$ & $-0,08$ \\
\hline Canaccord Genuity & $\mathrm{F}$ & 38 & 38 & 0 & 4 & $10,50 \%$ & 22 & $57,90 \%$ & 12 & $31,60 \%$ & $-0,21$ \\
\hline Cantor Fitzgerald & $\mathrm{F}$ & 7 & 7 & 0 & 7 & $100,00 \%$ & 0 & $0,00 \%$ & 0 & $0,00 \%$ & 1 \\
\hline Cenkos Securities Ltd & $\mathrm{F}$ & 1 & 1 & 0 & 0 & $0,00 \%$ & 1 & $100,00 \%$ & 0 & $0,00 \%$ & 0 \\
\hline Centrobanca & I & 49 & 49 & 0 & 23 & $46,90 \%$ & 20 & $40,80 \%$ & 6 & $12,20 \%$ & 0,35 \\
\hline Churchill Research & $\mathrm{F}$ & 1 & 0 & 1 & 0 & $0,00 \%$ & 0 & $0,00 \%$ & 0 & $0,00 \%$ & 0 \\
\hline CM Research & $\mathrm{F}$ & 3 & 3 & 0 & 2 & $66,70 \%$ & 0 & $0,00 \%$ & 1 & $33,30 \%$ & 0,33 \\
\hline Commerzbank & $\mathrm{F}$ & 9 & 9 & 0 & 0 & $0,00 \%$ & 0 & $0,00 \%$ & 9 & $100,00 \%$ & -1 \\
\hline Credit Suisse & $\mathrm{F}$ & 285 & 282 & 3 & 89 & $31,60 \%$ & 116 & $41,10 \%$ & 77 & $27,30 \%$ & 0,04 \\
\hline
\end{tabular}




\begin{tabular}{|c|c|c|c|c|c|c|c|c|c|c|c|}
\hline Davy & $\mathrm{F}$ & 13 & 13 & 0 & 3 & $23,10 \%$ & 3 & $23,10 \%$ & 7 & $53,80 \%$ & $-0,31$ \\
\hline Day by Day & $\mathrm{F}$ & 142 & 142 & 0 & 47 & $33,10 \%$ & 79 & $55,60 \%$ & 16 & $11,30 \%$ & 0,22 \\
\hline DNB Markets & $\mathrm{F}$ & 13 & 13 & 0 & 1 & $7,70 \%$ & 5 & $38,50 \%$ & 7 & $53,80 \%$ & $-0,46$ \\
\hline DZ Bank AG & $\mathrm{F}$ & 21 & 21 & 0 & 7 & $33,30 \%$ & 0 & $0,00 \%$ & 14 & $66,70 \%$ & $-0,33$ \\
\hline Equita SIM SpA & I & 623 & 623 & 0 & 290 & $46,50 \%$ & 314 & $50,40 \%$ & 19 & $3,00 \%$ & 0,43 \\
\hline Erste Group & $\mathrm{F}$ & 5 & 5 & 0 & 0 & $0,00 \%$ & 4 & $80,00 \%$ & 1 & $20,00 \%$ & $-0,2$ \\
\hline EVA Dimensions & $\mathrm{F}$ & 395 & 395 & 0 & 117 & $29,60 \%$ & 108 & $27,30 \%$ & 170 & $43,00 \%$ & $-0,13$ \\
\hline Evercore ISI & $\mathrm{F}$ & 40 & 40 & 0 & 14 & $35,00 \%$ & 14 & $35,00 \%$ & 12 & $30,00 \%$ & 0,05 \\
\hline Exane BNP Paribas & $\mathrm{F}$ & 499 & 499 & 0 & 163 & $32,70 \%$ & 197 & $39,50 \%$ & 139 & $27,90 \%$ & 0,05 \\
\hline Fidentiis Equities & $\mathrm{F}$ & 170 & 170 & 0 & 78 & $45,90 \%$ & 66 & $38,80 \%$ & 26 & $15,30 \%$ & 0,31 \\
\hline Freedom Finance & $\mathrm{F}$ & 2 & 2 & 0 & 2 & $100,00 \%$ & 0 & $0,00 \%$ & 0 & $0,00 \%$ & 1 \\
\hline Gabelli \& Co & $\mathrm{F}$ & 1 & 1 & 0 & 1 & $100,00 \%$ & 0 & $0,00 \%$ & 0 & $0,00 \%$ & 1 \\
\hline Goldman Sachs & $\mathrm{F}$ & 495 & 481 & 14 & 18 & $3,70 \%$ & 390 & $81,10 \%$ & 73 & $15,20 \%$ & $-0,11$ \\
\hline Grupo Santander & $\mathrm{F}$ & 107 & 107 & 0 & 55 & $51,40 \%$ & 27 & $25,20 \%$ & 25 & $23,40 \%$ & 0,28 \\
\hline Haitong & $\mathrm{F}$ & 49 & 49 & 0 & 27 & $55,10 \%$ & 20 & $40,80 \%$ & 2 & $4,10 \%$ & 0,51 \\
\hline Hamburger Sparkasse & $\mathrm{F}$ & 41 & 41 & 0 & 9 & $22,00 \%$ & 27 & $65,90 \%$ & 5 & $12,20 \%$ & 0,1 \\
\hline Hammer Partners SA & $\mathrm{F}$ & 143 & 143 & 0 & 99 & $69,20 \%$ & 14 & $9,80 \%$ & 30 & $21,00 \%$ & 0,48 \\
\hline HSBC & $\mathrm{F}$ & 260 & 260 & 0 & 102 & $39,20 \%$ & 119 & $45,80 \%$ & 39 & $15,00 \%$ & 0,24 \\
\hline ICBPI & I & 390 & 339 & 51 & 157 & $46,30 \%$ & 123 & $36,30 \%$ & 59 & $17,40 \%$ & 0,29 \\
\hline Independent Research GmbH & $\mathrm{F}$ & 120 & 120 & 0 & 14 & $11,70 \%$ & 72 & $60,00 \%$ & 34 & $28,30 \%$ & $-0,17$ \\
\hline ING Bank & $\mathrm{F}$ & 20 & 20 & 0 & 3 & $15,00 \%$ & 14 & $70,00 \%$ & 3 & $15,00 \%$ & 0 \\
\hline Insight Investment Research LLP & $\mathrm{F}$ & 13 & 13 & 0 & 13 & $100,00 \%$ & 0 & $0,00 \%$ & 0 & $0,00 \%$ & 1 \\
\hline Intermonte Securities SpA & I & 1 & 1 & 0 & 0 & $0,00 \%$ & 1 & $100,00 \%$ & 0 & $0,00 \%$ & 0 \\
\hline Investec & $\mathrm{F}$ & 28 & 28 & 0 & 11 & $39,30 \%$ & 11 & $39,30 \%$ & 6 & $21,40 \%$ & 0,18 \\
\hline J.P. Morgan & $\mathrm{F}$ & 349 & 349 & 0 & 130 & $37,20 \%$ & 174 & $49,90 \%$ & 45 & $12,90 \%$ & 0,24 \\
\hline Jefferies & $\mathrm{F}$ & 125 & 125 & 0 & 56 & $44,80 \%$ & 60 & $48,00 \%$ & 9 & $7,20 \%$ & 0,38 \\
\hline Keefe, Bruyette \& Woods & $\mathrm{F}$ & 142 & 142 & 0 & 39 & $27,50 \%$ & 72 & $50,70 \%$ & 31 & $21,80 \%$ & 0,06 \\
\hline Kempen \& Co & $\mathrm{F}$ & 4 & 4 & 0 & 2 & $50,00 \%$ & 2 & $50,00 \%$ & 0 & $0,00 \%$ & 0,5 \\
\hline Kepler Cheuvreux & $\mathrm{F}$ & 564 & 562 & 2 & 256 & $45,60 \%$ & 242 & $43,10 \%$ & 64 & $11,40 \%$ & 0,34 \\
\hline KeyBanc Capital Markets & $\mathrm{F}$ & 1 & 1 & 0 & 1 & $100,00 \%$ & 0 & $0,00 \%$ & 0 & $0,00 \%$ & 1 \\
\hline Landesbank Baden-Wuerttemberg & $\mathrm{F}$ & 109 & 109 & 0 & 29 & $26,60 \%$ & 43 & $39,40 \%$ & 37 & $33,90 \%$ & $-0,07$ \\
\hline Liberum & $\mathrm{F}$ & 65 & 65 & 0 & 7 & $10,80 \%$ & 52 & $80,00 \%$ & 6 & $9,20 \%$ & 0,02 \\
\hline Macquarie & $\mathrm{F}$ & 156 & 156 & 0 & 74 & $47,40 \%$ & 40 & $25,60 \%$ & 42 & $26,90 \%$ & 0,21 \\
\hline MainFirst Bank AG & $\mathrm{F}$ & 213 & 213 & 0 & 114 & $53,50 \%$ & 44 & $20,70 \%$ & 55 & $25,80 \%$ & 0,28 \\
\hline Makor Capital & $\mathrm{F}$ & 11 & 11 & 0 & 10 & $90,90 \%$ & 1 & $9,10 \%$ & 0 & $0,00 \%$ & 0,91 \\
\hline Mediobanca SpA & I & 619 & 601 & 18 & 330 & $54,90 \%$ & 237 & $39,40 \%$ & 34 & $5,70 \%$ & 0,49 \\
\hline Mirabaud Securities & $\mathrm{F}$ & 24 & 24 & 0 & 6 & $25,00 \%$ & 18 & $75,00 \%$ & 0 & $0,00 \%$ & 0,25 \\
\hline Morgan Stanley & $\mathrm{F}$ & 332 & 327 & 5 & 105 & $32,10 \%$ & 211 & $64,50 \%$ & 11 & $3,40 \%$ & 0,29 \\
\hline Morningstar, Inc & $\mathrm{F}$ & 130 & 130 & 0 & 37 & $28,50 \%$ & 86 & $66,20 \%$ & 7 & $5,40 \%$ & 0,23 \\
\hline $\mathrm{N}+1$ Singer Ltd & $\mathrm{F}$ & 9 & 9 & 0 & 4 & $44,40 \%$ & 5 & $55,60 \%$ & 0 & $0,00 \%$ & 0,44 \\
\hline National Bank AG & $\mathrm{F}$ & 22 & 22 & 0 & 5 & $22,70 \%$ & 14 & $63,60 \%$ & 3 & $13,60 \%$ & 0,09 \\
\hline Natixis & $\mathrm{F}$ & 271 & 271 & 0 & 80 & $29,50 \%$ & 155 & $57,20 \%$ & 36 & $13,30 \%$ & 0,16 \\
\hline New Street Research & $\mathrm{F}$ & 16 & 16 & 0 & 5 & $31,30 \%$ & 7 & $43,80 \%$ & 4 & $25,00 \%$ & 0,06 \\
\hline Nomura & $\mathrm{F}$ & 255 & 255 & 0 & 70 & $27,50 \%$ & 108 & $42,40 \%$ & 77 & $30,20 \%$ & $-0,03$ \\
\hline Nord/LB & $\mathrm{F}$ & 8 & 8 & 0 & 2 & $25,00 \%$ & 5 & $62,50 \%$ & 1 & $12,50 \%$ & 0,13 \\
\hline Oddo \& Cie & $\mathrm{F}$ & 154 & 154 & 0 & 48 & $31,20 \%$ & 63 & $40,90 \%$ & 43 & $27,90 \%$ & 0,03 \\
\hline Piper Jaffray & $\mathrm{F}$ & 13 & 13 & 0 & 0 & $0,00 \%$ & 12 & $92,30 \%$ & 1 & $7,70 \%$ & $-0,08$ \\
\hline Raymond James & $\mathrm{F}$ & 91 & 91 & 0 & 59 & $64,80 \%$ & 20 & $22,00 \%$ & 12 & $13,20 \%$ & 0,52 \\
\hline RBC Capital Markets & $\mathrm{F}$ & 158 & 158 & 0 & 61 & $38,60 \%$ & 74 & $46,80 \%$ & 23 & $14,60 \%$ & 0,24 \\
\hline Redburn & $\mathrm{F}$ & 70 & 70 & 0 & 20 & $28,60 \%$ & 29 & $41,40 \%$ & 21 & $30,00 \%$ & $-0,01$ \\
\hline S\&P Capital IQ & $\mathrm{F}$ & 105 & 105 & 0 & 29 & $27,60 \%$ & 43 & $41,00 \%$ & 33 & $31,40 \%$ & $-0,04$ \\
\hline Seaport Global Securities & $\mathrm{F}$ & 11 & 11 & 0 & 0 & $0,00 \%$ & 9 & $81,80 \%$ & 2 & $18,20 \%$ & $-0,18$ \\
\hline SEB Equities & $\mathrm{F}$ & 7 & 7 & 0 & 0 & $0,00 \%$ & 7 & $100,00 \%$ & 0 & $0,00 \%$ & 0 \\
\hline Silvia Quandt Research & $\mathrm{F}$ & 3 & 3 & 0 & 0 & $0,00 \%$ & 2 & $66,70 \%$ & 1 & $33,30 \%$ & $-0,33$ \\
\hline Societe Generale & $\mathrm{F}$ & 322 & 321 & 1 & 123 & $38,30 \%$ & 130 & $40,50 \%$ & 68 & $21,20 \%$ & 0,17 \\
\hline Spin-Off Research & $\mathrm{F}$ & 9 & 9 & 0 & 6 & $66,70 \%$ & 3 & $33,30 \%$ & 0 & $0,00 \%$ & 0,67 \\
\hline Stifel & $\mathrm{F}$ & 4 & 4 & 0 & 1 & $25,00 \%$ & 3 & $75,00 \%$ & 0 & $0,00 \%$ & 0,25 \\
\hline UBS & $\mathrm{F}$ & 284 & 284 & 0 & 104 & $36,60 \%$ & 146 & $51,40 \%$ & 34 & $12,00 \%$ & 0,25 \\
\hline Value Investment Principals & $\mathrm{F}$ & 1 & 1 & 0 & 1 & $100,00 \%$ & 0 & $0,00 \%$ & 0 & $0,00 \%$ & 1 \\
\hline VTB Capital & $\mathrm{F}$ & 7 & 7 & 0 & 0 & $0,00 \%$ & 7 & $100,00 \%$ & 0 & $0,00 \%$ & 0 \\
\hline WestLB Equity Markets & $\mathrm{F}$ & 5 & 5 & 0 & 0 & $0,00 \%$ & 4 & $80,00 \%$ & 1 & $20,00 \%$ & $-0,2$ \\
\hline WhiteSand Research LLC & $\mathrm{F}$ & 1 & 1 & 0 & 1 & $100,00 \%$ & 0 & $0,00 \%$ & 0 & $0,00 \%$ & 1 \\
\hline Whitman Howard & $\mathrm{F}$ & 2 & 2 & 0 & 1 & $50,00 \%$ & 1 & $50,00 \%$ & 0 & $0,00 \%$ & 0,5 \\
\hline William Blair \& Co & $\mathrm{F}$ & 14 & 14 & 0 & 1 & $7,10 \%$ & 13 & $92,90 \%$ & 0 & $0,00 \%$ & 0,07 \\
\hline Williams Financial Group & $\mathrm{F}$ & 1 & 1 & 0 & 0 & $0,00 \%$ & 1 & $100,00 \%$ & 0 & $0,00 \%$ & 0 \\
\hline
\end{tabular}




\section{Notes}

Note 1. Detailed broker data are shown in Table 17 in the appendix

Note 2. Recommendations are operational suggestions on the best behavior to adopt in relation to the financial tool in question. Once the target price is established, it is usually followed by a recommendation which varies according to the rating system adopted by the intermediary.

Note 3. Target prices are a prediction of the market value that, according to analysts, can be reached by the securities under consideration in the future. Even if the target price can get close to the fair value estimated through evaluation models, it may not coincide with it, since in defining the target price some elements can interfere and alter its value. Enterprise value can be defined through different models that analysts use singularly or jointly, depending on different variables, such as type of company, its assets, stock markets status, etc. Target price forecasts are referred to a medium-term time horizon, usually 12 months, although not all analysts specify this important aspect explicitly

Note 4. The TP/P ratio is the index calculated in this way: $T P / P=\frac{\text { target price }}{\text { price }}-1$

Note 5 . The number of reports increases every year, even not in a regular progression: $+0.3 \%$ from $2013 / 2012 ;+13.3 \%$ from 2014/2013; +7.8\% from 2015/2015 and $+5.8 \%$ from 2016/2015. 